\title{
Synthesis of Bridgehead Allylsilanes and Stereoselective Reactions with Aldehydes
}

Ryan Lauchli, John M. Whitney, Liang Zhu, and Kenneth J. Shea*

Department of Chemistry, 516 Rowland Hall, University of California, Irvine, Irvine, CA 92697-2025

kjshea@uci.edu

\section{Experimental Section}

Instrumentation: NMR measurements were conducted with Bruker instruments at 500 $\mathrm{MHz}$ for proton spectra and $125 \mathrm{MHz}$ for carbon spectra. Chemical shifts are given in ppm values referenced to residual solvent peaks. ${ }^{1}$ IR spectra were performed on a Perkin Elmer 1600 Series FTIR or MIDAC Prospect FT-IR spectrometer. High resolution mass spectral data were collected on a TOF instrument using electrospray ionization.

General Procedures: Toluene, THF, benzene, and $\mathrm{CH}_{2} \mathrm{Cl}_{2}$ were purified by passage through alumina columns as described by Grubbs. ${ }^{2}$ All reactions were performed under $\mathrm{N}_{2}$ using oven or flame dried glassware and standard syringe and septa techniques. Removal of solvent in vacuo refers to use of a Büchi rotary evaporator. Reagents were purchased from VWR, Fisher, or Aldrich and generally used without purification. Benzaldehyde, butyraldehyde, and isobutyraldehyde were distilled at atmospheric pressure under $\mathrm{N}_{2}$. $m$-Nitrobenzaldehyde was recrystallized from hexanes and ether. $\mathrm{TiCl}_{4}$ was stored under $\mathrm{Ar}$ in a glovebox. Trienes were stored at $-20{ }^{\circ} \mathrm{C}$ as frozen solutions in benzene. The trienes were warmed to RT and concentrated in vacuo just

\footnotetext{
${ }^{1}$ Gottieb, H. E.; Kotlyar, V.; Nudelman, A. J. Org. Chem. 1997, 62, 7512.

${ }^{2}$ Pangborn, A. B.; Giardello, M. A.; Grubbs, R. H.; Rosen, R. K.; Timmers, F.J. Organometallics 1996, 15 , 1518.
} 
before use. TLC was performed with aluminum-backed silica gel $60 \mathrm{~F}_{254}$ analytical plates from EMD. Visualization of compound spots was done with a short wave UV lamp followed by staining with either anisaldehyde or Seebach's stain (phosphomolybdic acid and $\left.\mathrm{Ce}_{2}\left(\mathrm{SO}_{4}\right)_{3}\right)$. Flash chromatography was performed on Geduran silica gel 60 (40-63 $\mu \mathrm{m})$ from EMD.

General Synthesis of Trienes

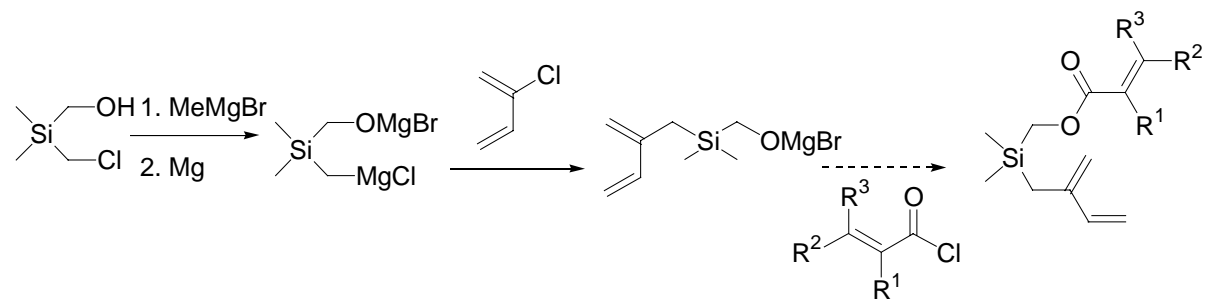

Hydroxymethyl(2-methylene-3-butenyl)dimethylsilane magnesium bromide salt solution was prepared in bulk and reacted with the appropriate acid chlorides.

\section{Hydroxymethyl(2-methylene-3-butenyl)dimethylsilane}

magnesium

\section{bromide salt solution}<smiles>C=CC(=C)C[Si](C)(C)CO[Mg]Br</smiles>

Chloromethyldimethylhydroxymethylsilane $\mathrm{e}^{3}(43.13 \mathrm{~g}, 311 \mathrm{mmol})$ and a few crystals of 1,10-phenanthroline were dissolved in THF ( $300 \mathrm{~mL})$ and the solution was cooled to -30 ${ }^{\circ} \mathrm{C}$. To this solution was added $\mathrm{CH}_{3} \mathrm{MgBr}(3.0 \mathrm{M}, 104 \mathrm{~mL}, 311 \mathrm{mmol})$ dropwise, keeping

${ }^{3}$ Prepared according to Whitney, J. M.; Parnes, J. S.; Shea, K. J. J. Org. Chem. 1997, 62, 8962, with the following modification in the conversion of bis(hydroxymethyl)dimethylsilane to chloromethyldimethylhydroxymethylsilane: 1) The chloroform used in this reaction was found to work best after extended storage over $4 \AA$ molecular sieves in the presence of ambient lighting. Presumably, $\mathrm{HCl}$ is developed over time and catalyzes the reaction. 2) The solvent used to triturate triphenylphosphine oxide must be ether, as hexanes do not adequately solvate the product. 
the solution $<-30{ }^{\circ} \mathrm{C}$. Upon completion of addition, the solution became heterogeneous. The mixture was allowed to warm to $0{ }^{\circ} \mathrm{C}$ and solids dissolved. Magnesium turnings $(7.56 \mathrm{~g}, 311 \mathrm{mmol})$ were added in one portion and the reaction was refluxed for $12 \mathrm{~h}$. The reaction was cooled to $0{ }^{\circ} \mathrm{C}$ and $\mathrm{NiCl}_{2} \mathrm{dppp}$ catalyst (3.37 g, $62.2 \mathrm{mmol}$ ) was added followed by freshly distilled chloroprene $(43.31 \mathrm{~mL}, 466.6 \mathrm{mmol})$ in a dropwise manner. An exotherm was observed after some of the chloroprene was added. The reaction was heated to a mild reflux for $3 \mathrm{~h}$ to complete the coupling. The reaction mixture was then used directly for dienophile coupling after determining the concentration of an aliquot via titration with $5 \mathrm{M} \mathrm{HCl}$ and phenolphthalein as an indicator.

\section{Dimethyl(2-methylene-3-butenyl)silylmethyl acrylate [5a]}

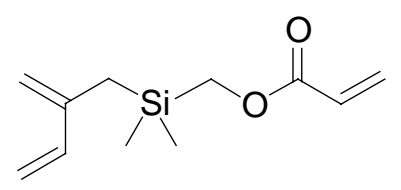

Hydroxymethyl(2-methylene-3-butenyl)dimethylsilane magnesium bromide salt solution $(0.80 \mathrm{M}, 20 \mathrm{~mL}, 16 \mathrm{mmol})$ was cooled to $-30{ }^{\circ} \mathrm{C}$ under $\mathrm{N}_{2}$. Acryloylchloride $(1.43 \mathrm{~mL}$, $17.6 \mathrm{mmol}$ ) was injected quickly and the reaction was warmed to RT over 30 min. Water was added to quench the reaction and the organics were extracted with hexanes. The combined hexane extracts were dried over $\mathrm{MgSO}_{4}$, filtered, and concentrated in vacuo. The residue was purified by $\mathrm{SiO}_{2}$ flash chromatography (95:5 hexanes:EtOAc) to give the product as a colorless oil. Yield: $3.10 \mathrm{~g}, 92 \%$. Rf 0.45 (90:10 hexane:EtOAc). ${ }^{1} \mathrm{H}$ NMR $\left(300 \mathrm{MHz}, \mathrm{CDCl}_{3}\right) 6.39(\mathrm{dd}, J=17.8,10.6 \mathrm{~Hz}, 1 \mathrm{H}), 6.38(\mathrm{dd}, J=17.5,1.70 \mathrm{~Hz}, 1 \mathrm{H})$, $6.13(\mathrm{dd}, J=17.5,10.6 \mathrm{~Hz}, 1 \mathrm{H}), 5.79(\mathrm{dd}, J=10.1,1.67 \mathrm{~Hz}, 1 \mathrm{H}), 5.13(\mathrm{~d}, J=17.9 \mathrm{~Hz}$, $1 \mathrm{H}), 5.06(\mathrm{~d}, J=12.6 \mathrm{~Hz}, 1 \mathrm{H}), 4.94(\mathrm{~d}, J=1.48 \mathrm{~Hz}, 1 \mathrm{H}), 4.84(\mathrm{~s}, 1 \mathrm{H}), 3.87(\mathrm{~s}, 2 \mathrm{H})$, 
$1.81(\mathrm{~d}, J=0.84 \mathrm{~Hz}, 2 \mathrm{H}), 0.085(\mathrm{~s}, 6 \mathrm{H}) .{ }^{13} \mathrm{C} \mathrm{NMR}\left(75.4 \mathrm{MHz}, \mathrm{CDCl}_{3}\right) 166.80,142.84$, 139.46, 130.00, 128.29, 114.82, 113.61, 56.34, 17.96, -4.53. IR 2928, 1727, 1403. HRMS EI [M- $\left.\mathrm{C}_{5} \mathrm{H}_{7}\right]$ found 143.0550, calculated for $\mathrm{C}_{6} \mathrm{H}_{11} \mathrm{O}_{2} \mathrm{Si} 143.0528$.

\section{Dimethyl(2-methylene-3-butenyl)silylmethyl methacrylate [5b]}

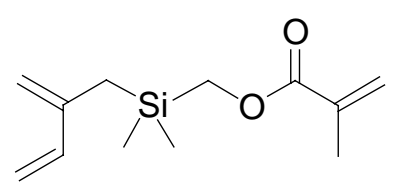

Hydroxymethyl(2-methylene-3-butenyl)dimethylsilane magnesium bromide salt solution $(0.80 \mathrm{M}, 20 \mathrm{~mL}, 16 \mathrm{mmol})$ was cooled to $-30^{\circ} \mathrm{C}$ under $\mathrm{N}_{2}$. Methacryloyl chloride $(1.72$ $\mathrm{mL}, 17.6 \mathrm{mmol}$ ) was injected quickly and the reaction warmed to RT over $30 \mathrm{~min}$. Water was added to quench the reaction and the organics were extracted with hexanes. The combined hexanes extracts were dried over $\mathrm{MgSO}_{4}$, filtered, and concentrated in vacuo. The yellow oil residue was purified by $\mathrm{SiO}_{2}$ flash chromatography (95:5 hexanes:EtOAc) to give the desired triene as a colorless oil. Yield $2.93 \mathrm{~g}, 82 \%$. Rf 0.55 (90:10 hexanes:EtOAc). ${ }^{1} \mathrm{H}$ NMR $\left(300 \mathrm{MHz}, \mathrm{CDCl}_{3}\right) 6.37(\mathrm{dd}, J=17.2,10.8 \mathrm{~Hz}, 1 \mathrm{H}), 6.06(\mathrm{~d}$, $J=0.69 \mathrm{~Hz}, 1 \mathrm{H}), 5.51(\mathrm{~m}, 1 \mathrm{H}), 5.11(\mathrm{~d}, \mathrm{~J}=17.3 \mathrm{~Hz}, 1 \mathrm{H}), 5.05(\mathrm{~d}, \mathrm{~J}=10.3 \mathrm{~Hz}, 1 \mathrm{H})$, $4.93(\mathrm{~d}, J=1.15 \mathrm{~Hz}, 1 \mathrm{H}), 4.83(\mathrm{~s}, 1 \mathrm{H}), 3.83(\mathrm{~s}, 2 \mathrm{H}), 1.93(\mathrm{~m}, 3 \mathrm{H}), 1.80(\mathrm{~d}, J=0.97$ $\mathrm{Hz}, 2 \mathrm{H}), 0.079$ (s, $6 \mathrm{H}) .{ }^{13} \mathrm{C} \mathrm{NMR}\left(75.4 \mathrm{MHz}, \mathrm{CDCl}_{3}\right)$ 169.14, 142.89, 139.64, 136.48, 124.89, 114.92, 113.69, 56.54, 18.41, 18.24, -4.33. IR 1720, 1335, 1161, 845. HRMS CI [M- $\mathrm{C}_{4} \mathrm{H}_{5} \mathrm{O}$ ] found 155.0966, calculated for $\mathrm{C}_{8} \mathrm{H}_{15} \mathrm{OSi}$ 155.0892. 


\section{Dimethyl(2-methylene-3-butenyl)silylmethyl crotonate [5c]}

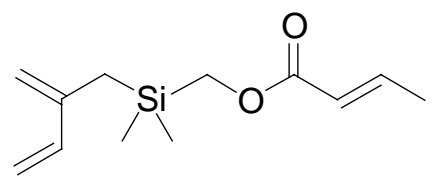

Hydroxymethyl(2-methylene-3-butenyl)dimethylsilane magnesium bromide salt solution $(0.80 \mathrm{M}, 20 \mathrm{~mL}, 16 \mathrm{mmol})$ was cooled to $-30^{\circ} \mathrm{C}$ under $\mathrm{N}_{2}$. Crotonoyl chloride $(1.98 \mathrm{~mL}$, $17.6 \mathrm{mmol}$ ) was injected quickly and the reaction was warmed to RT over $30 \mathrm{~min}$. Water was added to quench the reaction and the organics were extracted with hexane. The combined organics were dried over $\mathrm{MgSO}_{4}$, filtered, and concentrated in vacuo. The residue was purified by $\mathrm{SiO}_{2}$ flash chromatography (95:5 hexanes:EtOAc) to give the product as a colorless oil. Yield: $3.41 \mathrm{~g}, 95 \%$. Rf 0.57 (90:10 hexane:EtOAc). ${ }^{1} \mathrm{H}$ NMR $\left(300 \mathrm{MHz}, \mathrm{CDCl}_{3}\right) 6.94(\mathrm{dq}, J=7.02,6.95 \mathrm{~Hz}, 1 \mathrm{H}), 6.36(\mathrm{dd}, J=17.4,10.8 \mathrm{~Hz}, 1 \mathrm{H})$, $5.84(\mathrm{dd}, J=15.5,1.72 \mathrm{~Hz}, 1 \mathrm{H}), 5.11(\mathrm{~d}, J=17.8 \mathrm{~Hz}, 1 \mathrm{H}), 5.04(\mathrm{~d}, J=11.0 \mathrm{~Hz}, 1 \mathrm{H})$, $4.92(\mathrm{~d}, J=0.93 \mathrm{~Hz}, 1 \mathrm{H}), 4.83(\mathrm{~s}, 1 \mathrm{H}), 3.81(\mathrm{~d}, J=3.46 \mathrm{~Hz}, 2 \mathrm{H}), 1.86(\mathrm{dd}, J=6.95$, $1.57 \mathrm{~Hz}, 3 \mathrm{H}), 1.8$ (s, $2 \mathrm{H}), 0.064$ (s, $6 \mathrm{H}) .{ }^{13} \mathrm{C}$ NMR (75.4 MHz, $\left.\mathrm{CDCl}_{3}\right)$ 167.29, 144.06, 142.94, 139.67, 122.66, 114.91, 113.71, 56.07, 18.15, 17.89, -4.39. IR 1724, 841. HRMS CI [M-CH 3 found 209.0997, calculated for $\mathrm{C}_{11} \mathrm{H}_{17} \mathrm{O}_{2} \mathrm{Si} 209.0998$.

\section{Dimethyl(2-methylene-3-butenyl)silylmethyl tiglate [5d]}

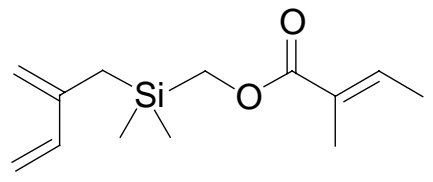


Hydroxymethyl(2-methylene-3-butenyl)dimethylsilane magnesium bromide salt solution $(0.80 \mathrm{M}, 20 \mathrm{~mL}, 16 \mathrm{mmol})$ was cooled to $-30^{\circ} \mathrm{C}$ under $\mathrm{N}_{2}$. Tiglyl chloride $(2.09 \mathrm{~g}, 17.6$ mmol) was injected quickly and the reaction was warmed to RT over 30 min. Water was added to quench the reaction and the organics were extracted with hexanes. The combined organics were dried over $\mathrm{MgSO}_{4}$, filtered, and concentrated in vacuo. The residue was purified by $\mathrm{SiO}_{2}$ flash chromatography (95:5 hexanes:EtOAc) to give the product as a colorless oil. Yield: $3.46 \mathrm{~g}, 95 \%$. Rf 0.25 (95:5 hexane:EtOAc). ${ }^{1} \mathrm{H}$ NMR $\left(300 \mathrm{MHz}, \mathrm{CDCl}_{3}\right) 6.80(\mathrm{dd}, J=5.59,1.40 \mathrm{~Hz}, 1 \mathrm{H}), 6.36(\mathrm{dd}, J=17.4,10.2 \mathrm{~Hz}, 1 \mathrm{H})$, $5.10(\mathrm{~d}, J=17.3 \mathrm{~Hz}, 1 \mathrm{H}), 5.03(\mathrm{~d}, J=11.3 \mathrm{~Hz}, 1 \mathrm{H}), 4.90(\mathrm{t}, J=1.00 \mathrm{~Hz}, 1 \mathrm{H}), 4.82(\mathrm{~s}, 1$ $\mathrm{H}), 3.80(\mathrm{~s}, 3 \mathrm{H}), 1.75-1.82(\mathrm{~m}, 8 \mathrm{H}), 0.064(\mathrm{~s}, 6 \mathrm{H}) .{ }^{13} \mathrm{C} \mathrm{NMR}\left(75.4 \mathrm{MHz}, \mathrm{CDCl}_{3}\right)$ $168.81,142.84,139.54,128.70,114.88,113.70,56.17,18.21,14.22,12.08,-4.35$. IR 1712, 737. HRMS CI [M+H] found 239.1470, calculated for $\mathrm{C}_{13} \mathrm{H}_{23} \mathrm{O}_{2} \mathrm{Si} 239.1467$.

\section{Dimethyl(2-methylene-3-butenyl)silylmethyl 2,2-dimethylacrylate [5e]}

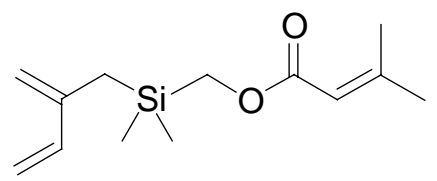

Hydroxymethyl(2-methylene-3-butenyl)dimethylsilane magnesium bromide salt solution (0.80 M, $20 \mathrm{~mL}, 16 \mathrm{mmol}$ ) was cooled to $-30^{\circ} \mathrm{C}$ under $\mathrm{N}_{2}$. 2,2-Dimethylacroyl chloride $(1.78 \mathrm{~mL}, 17.6 \mathrm{mmol})$ was injected quickly and the reaction was warmed to RT over 30 min. Water was added to quench the reaction and the organics were extracted with hexanes. The combined organics were dried over $\mathrm{MgSO}_{4}$, filtered, and concentrated in vacuo. The residue was purified by $\mathrm{SiO}_{2}$ flash chromatography (95:5 hexanes:EtOAc) to give the product as a colorless oil. Yield: $2.7 \mathrm{~g}, 71 \%$. Rf 0.59 (90:10 hexane:EtOAc). 
${ }^{1} \mathrm{H}$ NMR (300 MHz, CDCl $) 6.36(\mathrm{dd}, J=17.2,10.9 \mathrm{~Hz}, 1 \mathrm{H}), 5.67(\mathrm{t}, J=1.26 \mathrm{~Hz}, 1 \mathrm{H})$, $5.11(\mathrm{~d}, J=17.8 \mathrm{~Hz}, 1 \mathrm{H}), 5.04(\mathrm{~d}, J=10.7 \mathrm{~Hz}, 1 \mathrm{H}), 4.92(\mathrm{~d}, J=1.52 \mathrm{~Hz}, 1 \mathrm{H}), 4.83(\mathrm{~s}$, $1 \mathrm{H}), 3.76(\mathrm{~d}, J=3.56 \mathrm{~Hz}, 2 \mathrm{H}), 2.14(\mathrm{~d}, J=1.37 \mathrm{~Hz}, 3 \mathrm{H}), 1.88(\mathrm{~d}, J=1.21 \mathrm{~Hz}, 3 \mathrm{H})$, $1.79(\mathrm{~d}, J=0.77 \mathrm{~Hz}, 2 \mathrm{H}), 0.062(\mathrm{~s}, 6 \mathrm{H}) .{ }^{13} \mathrm{C}$ NMR $\left(75.4 \mathrm{MHz}, \mathrm{CDCl}_{3}\right) 167.51,155.86$, 143.00, 139.68, 116.04, 114.90, 113.75, 55.29, 27.28, 20.13, 18.15, -4.34. IR 1716, 1142. HRMS CI [M-CH 3 found 223.1151, calculated for $\mathrm{C}_{12} \mathrm{H}_{19} \mathrm{O}_{2} \mathrm{Si} 223.1155$.

\section{Dimethyl(2-methylene-3-butenyl)silylmethyl cinnamate [5f]}

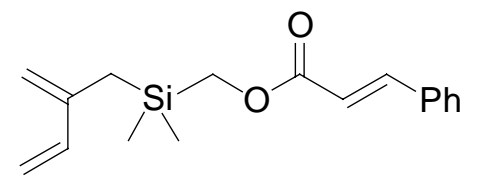

Chloromethyldimethylhydroxysilane (3.33 g, $24 \mathrm{mmol})$ was dissolved in THF (25 mL) and cooled to $-35{ }^{\circ} \mathrm{C}$. Methylmagnesium bromide $(2.76 \mathrm{M}, 9.56 \mathrm{~mL}, 26.4 \mathrm{mmol})$ was added dropwise keeping the temp below $-20^{\circ} \mathrm{C}$. The heterogeneous reaction was then warmed to RT and stirred for 20 min. Magnesium turnings $(0.64 \mathrm{~g}, 26.4 \mathrm{mmol})$ were added in one portion and then external heating was applied to bring the solution to reflux for $12 \mathrm{~h}$. The magnesium had been mostly consumed at this point. The reaction was cooled to $0{ }^{\circ} \mathrm{C}$ and the $\mathrm{NiCl}_{2} \mathrm{dppp}$ catalyst $(0.39 \mathrm{~g}, 0.72 \mathrm{mmol})$ was added. Freshly distilled chloroprene $(3.36 \mathrm{~mL}, 36 \mathrm{mmol})$ was then added dropwise. The solution exothermed and became heterogeneous. It was then poured into saturated aqueous $\mathrm{NH}_{4} \mathrm{Cl}$ and extracted with $\mathrm{Et}_{2} \mathrm{O}$. The combined ether abstracts were dried over $\mathrm{Na}_{2} \mathrm{SO}_{4}$,

filtered, and concentrated in vacuo. The resulting oily orange residue was purified by $\mathrm{SiO}_{2}$ flash chromatography (95:5 hexanes:EtOAc) to give the desired triene as a colorless 
oil. Yield $5.87 \mathrm{~g}, 85 \%$. Rf 0.44 (90:10 hexanes:EtOAc). ${ }^{1} \mathrm{H}$ NMR $\left(300 \mathrm{MHz}, \mathrm{CDCl}_{3}\right)$ $7.66(\mathrm{~d}, J=16.0 \mathrm{~Hz}, 1 \mathrm{H}), 7.53(\mathrm{~m}, 2 \mathrm{H}), 7.39(\mathrm{~m}, 3 \mathrm{H}), 6.45(\mathrm{~d}, J=16.1 \mathrm{~Hz}, 1 \mathrm{H}), 6.40$ $(\mathrm{dd}, J=17.4,10.7 \mathrm{~Hz}, 1 \mathrm{H}), 5.15(\mathrm{~d}, J=17.5 \mathrm{~Hz}, 1 \mathrm{H}), 5.08(\mathrm{~d}, J=10.7 \mathrm{~Hz}, 1 \mathrm{H}), 4.94$ (d, $J=0.68 \mathrm{~Hz}, 1 \mathrm{H}), 4.87$ (s, $1 \mathrm{H}), 3.92(\mathrm{~s}, 2 \mathrm{H}), 1.83(\mathrm{~s}, 2 \mathrm{H}), 0.12(\mathrm{~s}, 6 \mathrm{H}) .{ }^{13} \mathrm{C}$ NMR (75.5 MHz, $\left.\mathrm{CDCl}_{3}\right)$ 167.61, 144.22, 142.73, 139.49, 134.26, 130.00, 128.66, 127.85, 117.93, 114.89, 113.67, 56.41, 18.01, -4.44. IR 1712, 1639, 1587, 1331, 1162, 845. HRMS CI [M- $\left.\mathrm{C}_{5} \mathrm{H}_{7}\right]$ found 219.0860, calculated for $\mathrm{C}_{12} \mathrm{H}_{15} \mathrm{O}_{2} \mathrm{Si} 219.0843$.

\section{Dimethyl(2-methylene-3-butenyl)silylmethyl $\quad E$-2-bromomethacrylate} $[5 \mathrm{~g}]$

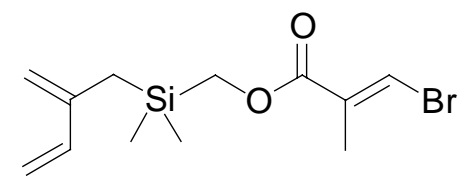

Prepared as described by Whitney, et. al. ${ }^{3}$

\section{Dimethyl(2-methylene-3-butenyl)silylmethyl furylate [5h]}

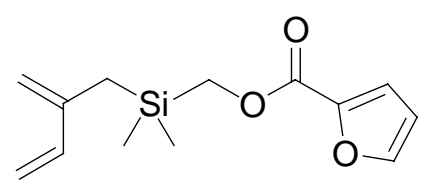

Hydroxymethyl(2-methylene-3-butenyl)dimethylsilane magnesium bromide salt solution $(0.80 \mathrm{M}, 20 \mathrm{~mL}, 16 \mathrm{mmol})$ was cooled to $-30{ }^{\circ} \mathrm{C}$ under $\mathrm{N}_{2}$. Furoyl chloride $(1.74 \mathrm{~mL}$, $17.6 \mathrm{mmol}$ ) was injected quickly and the reaction was warmed to RT over $30 \mathrm{~min}$. Water was added to quench the reaction and the organics were extracted with hexanes. The 
combined organics were dried over $\mathrm{MgSO}_{4}$, filtered, and concentrated in vacuo. The residue was purified by $\mathrm{SiO}_{2}$ flash chromatography (95:5 hexanes:EtOAc) to give the product as a colorless oil. Yield: $3.85 \mathrm{~g}, 96 \%$. Rf 0.42 (95:5 hexanes:EtOAc). ${ }^{1} \mathrm{H}$ NMR $\left(300 \mathrm{MHz}, \mathrm{CDCl}_{3}\right) 7.56(\mathrm{t}, J=0.84 \mathrm{~Hz}, 1 \mathrm{H}), 7.12(\mathrm{~d}, J=3.12 \mathrm{~Hz}, 1 \mathrm{H}), 6.49(\mathrm{dd}, J=$ 3.43, $1.69 \mathrm{~Hz}, 1 \mathrm{H}), 6.37(\mathrm{dd}, J=17.7,10.7 \mathrm{~Hz}, 1 \mathrm{H}), 5.13(\mathrm{~d}, J=17.4 \mathrm{~Hz}, 1 \mathrm{H}), 5.05(\mathrm{~d}$, $J=11.4 \mathrm{~Hz}, 1 \mathrm{H}), 4.94(\mathrm{~s}, 1 \mathrm{H}), 4.86(\mathrm{~s}, 1 \mathrm{H}), 3.99(\mathrm{~s}, 2 \mathrm{H}), 1.84(\mathrm{~d}, J=0.56 \mathrm{~Hz}, 2 \mathrm{H})$,

$0.12(\mathrm{~s}, 6 \mathrm{H}) .{ }^{13} \mathrm{C} \mathrm{NMR}\left(75.4 \mathrm{MHz}, \mathrm{CDCl}_{3}\right)$ 159.55, 146.12, 144.87, 142.82, 139.65, 117.34, 115.08, 113.83, 111.67, 56.94, 18.15, -4.31. IR 1722, 1315, 1119, 841, 764. HRMS CI [M-CH 3 ] found 235.0799, calculated for $\mathrm{C}_{12} \mathrm{H}_{15} \mathrm{O}_{3} \mathrm{Si} 235.0791$.

\section{Dimethyl(2-methylene-3-butenyl)silylmethyl methyl fumarate [5i]}

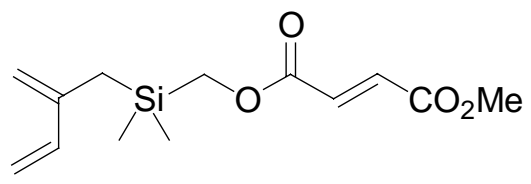

Hydroxymethyl(2-methylene-3-butenyl)dimethylsilane magnesium bromide salt solution $\left(0.80 \mathrm{M}, 20 \mathrm{~mL}, 16 \mathrm{mmol}\right.$ ) was cooled to $-30{ }^{\circ} \mathrm{C}$ under $\mathrm{N}_{2}$. Methyl fumaroyl chloride (2.60 g, $17.6 \mathrm{mmol}$ ) was added quickly and the reaction was warmed to RT over $30 \mathrm{~min}$. Water was added to quench the reaction and the organics were extracted with hexanes. The combined organics were dried over $\mathrm{MgSO}_{4}$, filtered, and concentrated in vacuo. The residue was purified by $\mathrm{SiO}_{2}$ flash chromatography (95:5 hexanes:EtOAc) to give the product as a colorless oil. Yield: $3.03 \mathrm{~g}, 71 \%$. Rf 0.63 (90:10 hexane:EtOAc). ${ }^{1} \mathrm{H}$ NMR $\left(300 \mathrm{MHz}, \mathrm{CDCl}_{3}\right) 6.85(\mathrm{~d}, J=15.8 \mathrm{~Hz}, 1 \mathrm{H}), 6.78(\mathrm{~d}, J=15.8 \mathrm{~Hz}, 1 \mathrm{H}), 6.34(\mathrm{dd}, J=$ 17.5, $10.7 \mathrm{~Hz}, 1 \mathrm{H}), 5.07(\mathrm{~d}, J=17.3 \mathrm{~Hz}, 1 \mathrm{H}), 5.02(\mathrm{~d}, J=10.3 \mathrm{~Hz}, 1 \mathrm{H}), 4.91(\mathrm{~s}, 1 \mathrm{H})$, $4.80(\mathrm{~s}, 1 \mathrm{H}), 3.88$ (s, $2 \mathrm{H}), 3.77$ (s, $3 \mathrm{H}), 1.78(\mathrm{~s}, 2 \mathrm{H}), 0.06$ (s, $6 \mathrm{H}) .{ }^{13} \mathrm{C}$ NMR $(75.4$ 
$\left.\mathrm{MHz}, \mathrm{CDCl}_{3}\right) 165.63,165.43,142.66,139.59,133.78,132.87,115.12,113.80,57.53$, 52.24, 18.09, -4.37. IR 2360, 1727, 1588, 1307, 1154, 849. HRMS CI [M+1] found 269.1205, calculated for $\mathrm{C}_{13} \mathrm{H}_{21} \mathrm{O}_{4} \mathrm{Si} 269.1209$.

\section{Dimethyl(2-methylene-3-butenyl)silylmethyl $E$-2-cyanocinnamate [5j]}

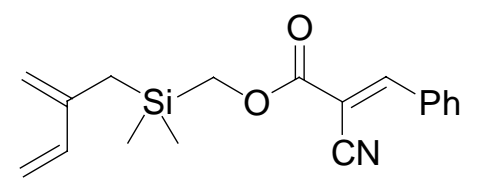

Hydroxymethyl(2-methylene-3-butenyl)dimethylsilane magnesium bromide salt solution $(0.80 \mathrm{M}, 20 \mathrm{~mL}, 16 \mathrm{mmol})$ was cooled to $-30{ }^{\circ} \mathrm{C}$ under $\mathrm{N}_{2}$. E-2-Cyanocinnamoyl chloride (3.37 g, $17.6 \mathrm{mmol}$ ) was added quickly and the reaction was warmed to RT over 30 min. Water was added to quench the reaction and the organics were extracted with hexanes. The combined organics were dried over $\mathrm{MgSO}_{4}$, filtered, and concentrated in vacuo. The residue was purified by $\mathrm{SiO}_{2}$ flash chromatography (95:5 hexanes:EtOAc) to give the product as a white powder. Yield: $3.58 \mathrm{~g}, 72 \%$. Rf 0.34 (90:10 hexane:EtOAc). ${ }^{1} \mathrm{H}$ NMR (300 MHz, CDCl $) 8.21(\mathrm{~s}, 1 \mathrm{H}), 7.96(\mathrm{~m}, 2 \mathrm{H}), 7.52(\mathrm{~m}, 3 \mathrm{H}), 6.38(\mathrm{dd}, J=$ 17.5, 10.7 Hz, $1 \mathrm{H}), 5.15(\mathrm{~d}, J=17.5 \mathrm{~Hz}, 1 \mathrm{H}), 5.07(\mathrm{~d}, J=10.7 \mathrm{~Hz}, 1 \mathrm{H}), 4.95(\mathrm{~d}, J=1.1$ $\mathrm{Hz}, 1 \mathrm{H}), 4.87$ (s, $1 \mathrm{H}), 4.01(\mathrm{~s}, 2 \mathrm{H}), 1.86(\mathrm{~d}, J=0.08 \mathrm{~Hz}, 2 \mathrm{H}), 0.14(\mathrm{~s}, 6 \mathrm{H}),{ }^{13} \mathrm{C}$ NMR (75.4 MHz, $\left.\mathrm{CDCl}_{3}\right)$ 165.41, 154.83, 142.67, 139.59, 133.26, 131.48, 131.06, 129.26, 115.25, 113.96, 102.91, 58.93, 18.08, -4.37. IR 2922, 2359, 1731, 1613, 1463. HRMS CI $\left[\mathrm{M}-\mathrm{C}_{5} \mathrm{H}_{7}\right]$ found 244.0793, calculated for $\mathrm{C}_{13} \mathrm{H}_{13} \mathrm{NO}_{2} \mathrm{Si} 244.0795$.

\section{5,5-Dimethyl-3-oxa-5-sila-bicyclo[5.3.1] unde-7-en-2-one [4a]}




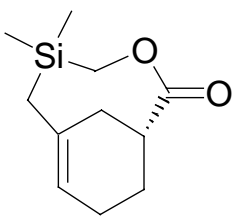

In a dry re-sealable glass tube, dimethyl(2-methylene-3-butenyl)silylmethyl acrylate (210 $\mathrm{mg}, 0.998 \mathrm{mmol})$ was dissolved in toluene $(100 \mathrm{~mL}, 0.01 \mathrm{M})$ and the solution was sparged with $\mathrm{N}_{2}$ gas for $10 \mathrm{~min}$. The solution was then heated at $200{ }^{\circ} \mathrm{C}$ for a total of $6.75 \mathrm{~h}$, and then allowed to cool to RT. The toluene was removed under reduced pressure to yield a colorless oil. The oil was purified by flash chromatography on $\mathrm{SiO}_{2}$ (95:5 hexanes:EtOAc) to give the product as a colorless oil. Yield: $168 \mathrm{mg}, 80 \%$. ${ }^{1} \mathrm{H}$ NMR $\left(300 \mathrm{MHz}, \mathrm{CDCl}_{3}\right) 5.29(\mathrm{~d}, J=3.95 \mathrm{~Hz}, 1 \mathrm{H}), 4.39(\mathrm{~d}, J=14.0 \mathrm{~Hz}, 1 \mathrm{H}), 3.56(\mathrm{~d}, J=$ 14.0 Hz, $1 \mathrm{H}), 2.89(\mathrm{~m}, 1 \mathrm{H}), 2.41(\mathrm{dt}, J=13.4,1.75 \mathrm{~Hz}, 1 \mathrm{H}), 2.11(\mathrm{~m}, 2 \mathrm{H}), 1.94(\mathrm{~s}, 1$ H), $1.90(\mathrm{~s}, 1 \mathrm{H}), 1.66(\mathrm{~d}, J=13.5 \mathrm{~Hz}, 1 \mathrm{H}), 1.63(\mathrm{~m}, 1 \mathrm{H}), 1.45(\mathrm{~d}, J=13.5 \mathrm{~Hz}, 1 \mathrm{H})$, 0.13 (s, $3 \mathrm{H}), 0.06$ (s, $3 \mathrm{H}) .{ }^{13} \mathrm{C}$ NMR $\left(75.4 \mathrm{MHz}, \mathrm{CDCl}_{3}\right)$ 177.91, 136.55, 121.51, 60.14, $41.75,35.90,25.51,22.75,21.44,-1.26,-1.78$. IR 2929, 1727, 1254, 839. HRMS CI $[\mathrm{M}+\mathrm{H}]$ found 211.1148, calculated for $\mathrm{C}_{11} \mathrm{H}_{19} \mathrm{O}_{2} \mathrm{Si}$.

\section{1,5,5-Trimethyl-3-oxa-5-sila-bicylco[5.3.1] undec-7-en-2-one [4b]}

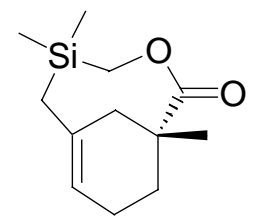

In a dry, re-sealable glass tube, dimethyl(2-methylene-3-butenyl)silylmethyl methacrylate (224 mg, $0.999 \mathrm{mmol}$ ) was dissolved in toluene $(100 \mathrm{~mL}, 0.01 \mathrm{M})$ and the $\mathrm{N}_{2}$ was bubbled through the solution for $10 \mathrm{~min}$. The solution was then heated at $200{ }^{\circ} \mathrm{C}$ for a total of $8.75 \mathrm{~h}$, and then allowed to cool to RT. The toluene was removed in vacuo to 
yield a colorless oil. The oil was purified by flash chromatography on $\mathrm{SiO}_{2}$ (95:5 hexanes:EtOAc) to give the product as a colorless oil. Yield: $201 \mathrm{mg}, 90 \%$. Rf 0.52 (10:90 hexanes:EtOAc). ${ }^{1} \mathrm{H}$ NMR $\left(300 \mathrm{MHz}, \mathrm{CDCl}_{3}\right) 5.28(\mathrm{~m}, 1 \mathrm{H}), 4.37(\mathrm{~d}, J=14.0$ $\mathrm{Hz}, 1 \mathrm{H}), 3.60$ (d, $J=14.0 \mathrm{~Hz}, 1 \mathrm{H}), 2.10-2.28(\mathrm{~m}, 4 \mathrm{H}), 1.70-1.93$ (m, $2 \mathrm{H}), 1.46$ (dd, $J=$ 13.5, $1.46 \mathrm{~Hz}, 1 \mathrm{H}), 1.36(\mathrm{~m}, 1 \mathrm{H}), 1.22(\mathrm{~s}, 3 \mathrm{H}), 0.20(\mathrm{~s}, 3 \mathrm{H}), 0.08(\mathrm{~s}, 3 \mathrm{H}),{ }^{13} \mathrm{C}$ NMR (75.4 MHz, $\left.\mathrm{CDCl}_{3}\right)$ 179.59, 136.38, 121.30, 60.11, 47.52, 43.63, 31.81, 25.65, 23.04, 22.79, $-0.94,-1.82$. IR 1731,802 . HRMS CI $[\mathrm{M}+1]$ found 225.1317 , calculated for $\mathrm{C}_{12} \mathrm{H}_{21} \mathrm{O}_{2} \mathrm{Si} 225.1311$.

\section{5,4,10-Trimethyl-3-oxa-5-sila-bicyclo[5.3.1] undec-7-en-2-one [4c]}

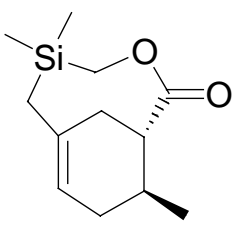

In a dry, re-sealable glass tube, dimethyl(2-methylene-3-butenyl)silylmethyl crotonate (224 mg, $0.999 \mathrm{mmol})$ was dissolved in toluene $(100 \mathrm{~mL}, 0.01 \mathrm{M})$ and the $\mathrm{N}_{2}$ was bubbled through the solution for $10 \mathrm{~min}$. The solution was then heated at $200{ }^{\circ} \mathrm{C}$ for a total of $66 \mathrm{~h}$, and then allowed to cool to RT. The toluene was removed in vacuo to yield a colorless oil. The oil was purified by flash chromatography on $\mathrm{SiO}_{2}$ (95:5 hexanes:EtOAc) to give the product as a wax. Yield: $210 \mathrm{mg}, 94 \%$. Rf 0.50 (10:90 EtOAc:hexanes). ${ }^{1} \mathrm{H}$ NMR $\left(300 \mathrm{MHz}, \mathrm{CDCl}_{3}\right) 5.41(\mathrm{~d}, J=1.02 \mathrm{~Hz}, 1 \mathrm{H}), 4.48(\mathrm{~d}, J=$ $13.5 \mathrm{~Hz}, 1 \mathrm{H}), 3.57(\mathrm{~d}, J=14.0 \mathrm{~Hz}, 1 \mathrm{H}), 2.28-2.55(\mathrm{~m}, 4 \mathrm{H}), 1.97(\mathrm{dd}, J=12.5,1.76 \mathrm{~Hz}$, $1 \mathrm{H}), 1.73(\mathrm{~m}, 1 \mathrm{H}), 1.51(\mathrm{~d}, J=13.9 \mathrm{~Hz}, 1 \mathrm{H}), 1.36(\mathrm{~m}, 1 \mathrm{H}), 1.00(\mathrm{~d}, J=7.24 \mathrm{~Hz}, 3 \mathrm{H})$, 0.12 (s, $6 \mathrm{H}) .{ }^{13} \mathrm{C}$ NMR $\left(75.4 \mathrm{MHz}, \mathrm{CDCl}_{3}\right)$ 177.65, 137.49, 122.59, 59.62, 49.60, 32.80, 
31.25, 27.86, 25.00, 21.20, -1.58. IR 1736, 1157. HRMS CI [M+1] found 225.1306, calculated for $\mathrm{C}_{12} \mathrm{H}_{21} \mathrm{O}_{2} \mathrm{Si} 225.1311$.

\section{1,5,5,10-Tetramethyl-3-oxa-5-sila-bicyclo[5.3.1]undec-7-en-2-one [4d]}

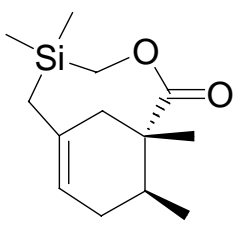

In a dry re-sealable glass tube, dimethyl(2-methylene-3-butenyl)silylmethyl tiglate (120 $\mathrm{mg}, 0.503 \mathrm{mmol}$ ) was dissolved in toluene $(50 \mathrm{~mL}, 0.01 \mathrm{M})$ and $\mathrm{N}_{2}$ was bubbled through the solution for $10 \mathrm{~min}$. The solution was then heated at $200{ }^{\circ} \mathrm{C}$ for a total of $100 \mathrm{~h}$, and then allowed to cool to RT. The toluene was removed under reduced pressure to yield a yellow oil. The oil was purified by flash chromatography on $\mathrm{SiO}_{2}$ (95:5 hexanes:EtOAc) to give the product as a colorless oil. Yield: $93 \mathrm{mg}, 77 \%$. ${ }^{1} \mathrm{H} \mathrm{NMR}\left(300 \mathrm{MHz}, \mathrm{CDCl}_{3}\right)$ $5.24(\mathrm{~d}, J=0.26 \mathrm{~Hz}, 1 \mathrm{H}), 4.38(\mathrm{~d}, J=14.1 \mathrm{~Hz}, 1 \mathrm{H}), 3.59(\mathrm{~d}, J=14.1 \mathrm{~Hz}, 1 \mathrm{H}), 2.45(\mathrm{~m}$, $2 \mathrm{H}), 2.06(\mathrm{~d}, J=13.2 \mathrm{~Hz}, 1 \mathrm{H}), 1.91(\mathrm{~d}, J=13.2 \mathrm{~Hz}, 1 \mathrm{H}), 1.71(\mathrm{~d}, J=13.5 \mathrm{~Hz}, 1 \mathrm{H})$, $1.45(\mathrm{~d}, J=13.4 \mathrm{~Hz}, 1 \mathrm{H}), 1.13(\mathrm{~s}, 3 \mathrm{H}), 0.88(\mathrm{~d}, J=6.74 \mathrm{~Hz}, 3 \mathrm{H}), 0.18(\mathrm{~s}, 3 \mathrm{H}), 0.07$ (s,

$3 \mathrm{H}) .{ }^{13} \mathrm{C} \mathrm{NMR}\left(75.4 \mathrm{MHz}, \mathrm{CDCl}_{3}\right)$ 180.24, 137.16, 121.27, 59.89, 51.07, 38.74, 32.78, $31.18,25.30,19.74,17.50,-1.01,-1.79$. IR 2960, 1736, 1454, 1142, 846. HRMS CI [M+1] found 239.1472, calculated for $\mathrm{C}_{13} \mathrm{H}_{23} \mathrm{O}_{2} \mathrm{Si} 239.1476$.

\section{5,5-Dimethyl-10-phenyl-3-oxa-5-sila-bicyclo[5.3.1] undec-7-en-2-one [4f]}

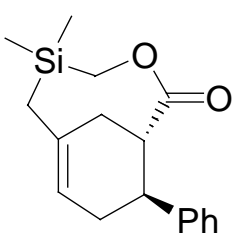


In a dry re-sealable glass tube, dimethyl(2-methylene-3-butenyl)silylmethyl cinnamate (430 mg, $1.5 \mathrm{mmol}$ ) was dissolved in toluene $(115 \mathrm{~mL}, 0.013 \mathrm{M})$ and $\mathrm{N}_{2}$ was bubbled through the solution for $10 \mathrm{~min}$. The solution was then heated at $200{ }^{\circ} \mathrm{C}$ for a total of 40 $\mathrm{h}$, and then allowed to cool to RT. The toluene was removed under reduced pressure to yield a yellow oil. The oil was purified by flash chromatography on $\mathrm{SiO}_{2}$ (95:5 hexanes:EtOAc) to give the product as a colorless solid. Yield: $413 \mathrm{mg}, 96 \%$. Mp: 72.874.5 ${ }^{\circ} \mathrm{C} .{ }^{1} \mathrm{H}$ NMR $\left(300 \mathrm{MHz}, \mathrm{CDCl}_{3}\right) 7.25(\mathrm{~m}, 5 \mathrm{H}), 5.49(\mathrm{~s}, 1 \mathrm{H}), 4.49$ (d, $J=14.0 \mathrm{~Hz}, 1$ H), $3.70(\mathrm{~m}, 1 \mathrm{H}), 3.67(\mathrm{~d}, J=14 \mathrm{~Hz}, 1 \mathrm{H}), 2.98(\mathrm{~m}, 1 \mathrm{H}), 2.66(\mathrm{~m}, 2 \mathrm{H}), 2.24(\mathrm{~d}, J=13.3$ $\mathrm{Hz}, 1 \mathrm{H}), 2.07$ (d, $J=16.6 \mathrm{~Hz}, 1 \mathrm{H}), 1.79(\mathrm{~d}, J=13.5 \mathrm{~Hz}, 1 \mathrm{H}), 1.58(\mathrm{~d}, J=13.0 \mathrm{~Hz}, 1$ H), 0.16 (s, $3 \mathrm{H}), 0.15$ (s, $3 \mathrm{H}) .{ }^{13} \mathrm{C}$ NMR $\left(75.4 \mathrm{~Hz}, \mathrm{CDCl}_{3}\right)$ 177.59, 146.65, 137.44, $128.48,127.55,126.09,121.49,60.58,49.56,39.49,33.14,30.53,25.52,-1.45,-1.69$. IR $\left(\mathrm{KBr}\right.$ pellet, $\left.\mathrm{cm}^{-1}\right): 3053,3025,2995,2952,2926,2912,2880,2844,1726,1416,1306$, $1281,1255,1245,1158,1148,839,802,749,709$. HRMS EI [M+] found 286.1384, calculated for $\mathrm{C}_{17} \mathrm{H}_{22} \mathrm{O}_{2} \mathrm{Si} \mathrm{C}_{17} \mathrm{H}_{22} \mathrm{O}_{2} \mathrm{Si} 286.1389$.

\section{0-Bromo-1,5,5-trimethyl-3-oxa-5-sila-bicyclo[5.3.1]undec-7-en-2-one}

\section{$[4 \mathrm{~g}]$}

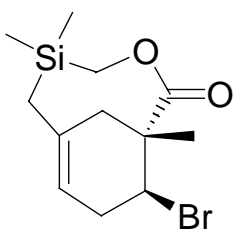

Prepared as described by Whitney, et. al. ${ }^{3}$ 


\section{5,5-Dimethyl-2-oxo-3-oxa-5-sila-bicyclo[5.3.1] undec-7-ene-10-carboxylic acid methyl ester [4i]}

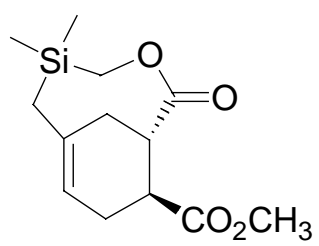

1-[Dimethyl(2-methylene-3-butenyl)]silylmethyl methyl fumarate (160 mg, $0.596 \mathrm{mmol})$ was dissolved in $\mathrm{N}_{2}$ purged benzene $(60 \mathrm{~mL})$ and heated to reflux. After $2.8 \mathrm{~d}$, the benzene was removed in vacuo to yield a yellow oily solid. The solid was dissolved in hexane and passed through a plug of $\mathrm{SiO}_{2}$, and then concentrated in vacuo to give the product as a white wax. Yield: $130 \mathrm{mg}, 81 \%$. Rf 0.28 (10:90 EtOAc:hexanes). ${ }^{1} \mathrm{H}$ NMR $\left(300 \mathrm{MHz}, \mathrm{CDCl}_{3}\right) 5.35(\mathrm{~d}, J=6.1 \mathrm{~Hz}, 1 \mathrm{H}), 4.48(\mathrm{~d}, J=13.9 \mathrm{~Hz}, 1 \mathrm{H}), 3.68(\mathrm{~s}, 3 \mathrm{H})$, $3.59(\mathrm{~d}, J=13.9 \mathrm{~Hz}, 1 \mathrm{H}), 3.34(\mathrm{~m}, 2 \mathrm{H}), 2.51(\mathrm{~m}, 1 \mathrm{H}), 2.42(\mathrm{dd}, J=8.7,7.2 \mathrm{~Hz}, 1 \mathrm{H})$, $2.10(\mathrm{~m}, 1 \mathrm{H}), 2.01(\mathrm{dd}, J=13.1,1.7 \mathrm{~Hz}, 1 \mathrm{H}), 1.72(\mathrm{~d}, J=13.6 \mathrm{~Hz}, 1 \mathrm{H}), 1.51(\mathrm{~d}, J=$ 13.6 Hz, $1 \mathrm{H}), 0.11(\mathrm{~s}, 3 \mathrm{H}), 0.10(\mathrm{~s}, 3 \mathrm{H}) .{ }^{13} \mathrm{C}$ NMR $\left(75.4 \mathrm{MHz}, \mathrm{CDCl}_{3}\right) 176.73,175.82$, 137.97, 120.18, 60.19, 51.94, 44.96, 39.78, 34.10, 25.08, 24.99, -1.58. IR 2919, 1737, 1455, 838. HRMS CI [M+1] found 269.1205, calculated for $\mathrm{C}_{13} \mathrm{H}_{21} \mathrm{O}_{4} \mathrm{Si} 269.1209$.

\section{5,5-Dimethyl-2-oxo-10-phenyl-3-oxa-5-sila-bicyclo[5.3.1] undec-7-ene-1- carbonitrile $[\mathbf{4} \mathbf{j}]$}

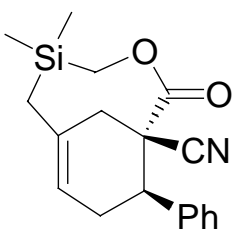


In a dry re-sealable glass tube, dimethyl(2-methylene-3-butenyl)silylmethyl E-2cyanocinnamate (100 mg, $0.321 \mathrm{mmol}$ ) was dissolved in toluene ( $32 \mathrm{~mL}, 0.01 \mathrm{M})$ and $\mathrm{N}_{2}$ was bubbled through the solution for $10 \mathrm{~min}$. The solution was then heated at $200{ }^{\circ} \mathrm{C}$ for a total of $45 \mathrm{~h}$, and then allowed to cool to RT. The toluene was removed in vacuo and the residue was purified by flash chromatography on $\mathrm{SiO}_{2}$ (95:5 hexanes:EtOAc) to give a mixture of regioisomers as a wax. The minor isomer is present as 5\% of the product. Rf 0.26 (90:10 hexanes:EtOAc). Yield: $89 \mathrm{mg}, 89 \% .{ }^{1} \mathrm{H} \mathrm{NMR}\left(300 \mathrm{MHz}, \mathrm{CDCl}_{3}\right)$ 7.27$7.40(\mathrm{~m}, 5 \mathrm{H}), 5.33(\mathrm{~m}, 1 \mathrm{H}), 4.51(\mathrm{~d}, J=14.2 \mathrm{~Hz}, 1 \mathrm{H}), 3.87(\mathrm{~d}, J=13.6 \mathrm{~Hz}, 1 \mathrm{H}), 3.84$ (m, $1 \mathrm{H}), 2.63-2.77(\mathrm{~m}, 3 \mathrm{H}), 2.40(\mathrm{~d}, J=18 \mathrm{~Hz}, 1 \mathrm{H}), 1.88(\mathrm{~d}, J=13.6 \mathrm{~Hz}, 1 \mathrm{H}), 1.59(\mathrm{~d}$, $J=13.4 \mathrm{~Hz}, 1 \mathrm{H}), 0.27(\mathrm{~s}, 3 \mathrm{H}), 0.18(\mathrm{~s}, 3 \mathrm{H}) .{ }^{13} \mathrm{C} \mathrm{NMR}\left(75.4 \mathrm{MHz}, \mathrm{CDCl}_{3}\right)$ 169.48, $140.93,134.30,129.73,129.15,128.45,127.61,121.94,117.28,62.88,49.81,42.03$, $36.38,30.18,25.58,-1.16,-1.88$. IR 2256, 1743, 1253, 837. HRMS CI [M+1] found 312.1386, calculated for $\mathrm{C}_{18} \mathrm{H}_{22} \mathrm{NO}_{2} \mathrm{Si} 312.1419$.

\section{[Dimethyl-(3-methyl-2-methylene-but-3-enyl)-silanyl]-methyl acrylate} [12]

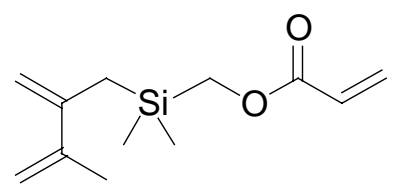

Chloromethylhydroxymethyldimethylsilane $(4.9 \mathrm{~g}, 35 \mathrm{mmol})$ was dissolved in dry THF (90 ml) under $\mathrm{N}_{2}$ and a few crystals of 1,10-phenanthroline monohydrate were added as an internal indicator. The solution was cooled below $-30{ }^{\circ} \mathrm{C}$ and magnetically stirred as $\mathrm{MeMgBr}$ (3.0 M in ether) was added dropwise until the mix became cloudy and acquired a slight pink tint (about $11 \mathrm{~mL}$ ). The mixture was allowed to warm to $\mathrm{rt}$ and all solids dissolved. The pink solution was transferred via cannula to a flask with excess $\mathrm{Mg}$ 
turnings $(4.8 \mathrm{~g})$ that had been activated by stirring overnight under $\mathrm{N}_{2}$. Initiation of the Grignard reaction was immediate. A condenser and magnetic stirring were used as the mixture exothermed. Heating was applied to maintain reflux for $1 \mathrm{~h}$. After cooling and standing at RT for $24 \mathrm{~h}$, the Grignard solution was transferred to another flask containing $\mathrm{NidpppCl}_{2}(0.67 \mathrm{~g}, 1.0 \mathrm{mmol})$ in order to separate the solution from the remaining solid Mg. Freshly prepared 2-chloro-3-methyl-buta-1,3-diene ${ }^{4}(5 \mathrm{~mL}, 51 \mathrm{mmol})$ was added dropwise as the mixture was magnetically stirred. The mixture was left to stir at RT for 3 $\mathrm{h}$, and then transferred via cannula to an ice-cooled flask containing acryloyl chloride ( $4.0 \mathrm{~g}, 44 \mathrm{mmol})$ in $50 \mathrm{~mL}$ of THF. This mixture was stirred for $1 \mathrm{~h}$ at RT. The mixture was partitioned between $\mathrm{Et}_{2} \mathrm{O}(500 \mathrm{~mL})$ and saturated aqueous $\mathrm{NH}_{4} \mathrm{Cl}$. The organic layer was washed twice with saturated aqueous $\mathrm{NaCl}$, dried over $\mathrm{Na}_{2} \mathrm{SO}_{4}$, and the solvents were removed in vacuo. The residue was purified by silica gel flash chromatography using EtOAc:hexanes (5:95) to give the product as a colorless liquid. Yield: $1.54 \mathrm{~g}$ (19\%). ${ }^{1} \mathrm{H}$ NMR $\left(500 \mathrm{MHz}, \mathrm{CDCl}_{3}\right) \delta 6.27(\mathrm{dd}, J=17.4,1.7 \mathrm{~Hz}, 1 \mathrm{H}), 6.05(\mathrm{dd}, J=$ 17.4, $10.5 \mathrm{~Hz}, 1 \mathrm{H}), 5.70$ (dd, $J=10.5,1.5 \mathrm{~Hz}, 1 \mathrm{H}), 4.88-4.94(\mathrm{~m}, 3 \mathrm{H}), 4.72(\mathrm{~s}, 1 \mathrm{H})$, 3.76 (s, $2 \mathrm{H}), 1.81-1.83$ (m, $3 \mathrm{H}), 1.78-1.80$ (m, $2 \mathrm{H}),-0.03$ (s, $6 \mathrm{H}) .{ }^{13} \mathrm{C}$ NMR (125 $\left.\mathrm{MHz}, \mathrm{DCCl}_{3}\right) \delta 167.1,144.4,143.4,130.2,113.7,111.3,56.8,21.1,20.9,-4.2$. IR ( $\mathrm{NaCl}$ film): 3084, 2956, 2903, 1723, 1632, 1590, 1404, 1303, 1249, 1180, 1053, 984, $888,845,813 \mathrm{~cm}^{-1}$.

\footnotetext{
${ }^{4}$ Carothers, W. H.; Coffman, D. D. J. Am. Chem. Soc. 1932, 54, 4071.
} 


\section{5,5,8-trimethyl-3-oxa-5-sila-bicyclo[5.3.1] undec-7-en-2-one [13]}

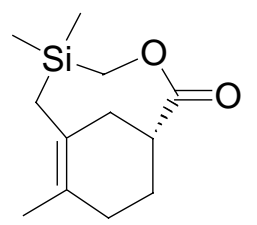

The triene $(170 \mathrm{mg}, 0.75 \mathrm{mmol})$ was dissolved in $50 \mathrm{~mL}$ of dry toluene to give a $0.015 \mathrm{M}$ solution. The solution was transferred to a heavy-walled re-sealable glass tube and was heated in an oil bath at $200{ }^{\circ} \mathrm{C}$ for $48 \mathrm{~h}$. The toluene was removed in vacuo and the residue was purified by silica gel flash chromatography using EtOAc:hexanes (5:95) to give the product as a colorless liquid (104 mg, $61 \%) .{ }^{1} \mathrm{H}$ NMR $\left(500 \mathrm{MHz}, \mathrm{C}_{6} \mathrm{D}_{6}\right) \delta 4.49$ $(\mathrm{d}, J=13.9 \mathrm{~Hz}, 1 \mathrm{H}), 3.42(\mathrm{~d}, J=14.2 \mathrm{~Hz}, 1 \mathrm{H}), 2.65(\mathrm{~m}, 1 \mathrm{H}), 2.30-2.37$ (m, $2 \mathrm{H}), 2.04$ (ddd, $J=16.0,9.3,3.9 \mathrm{~Hz}, 1 \mathrm{H}), 1.74-1.90(\mathrm{~m}, 4 \mathrm{H}), 1.52(\mathrm{~s}, 3 \mathrm{H}), 1.37-1.45(\mathrm{~m}, 1 \mathrm{H})$, $1.17(\mathrm{~d}, J=13.4 \mathrm{~Hz}, 1 \mathrm{H}), 0.02(\mathrm{~s}, 3 \mathrm{H}),-0.08(\mathrm{~s}, 3 \mathrm{H}) .{ }^{13} \mathrm{C} \mathrm{NMR}\left(125 \mathrm{MHz}, \mathrm{C}_{6} \mathrm{D}_{6}\right) \delta$ $177.5,59.7,41.8,37.4,28.2,23.7,22.7,19.9,-0.2,-0.9$. EIMS $m / z(\%)=224(64), 143$ (69), 91 (100). IR (NaCl film): 2903, 1734, 1446, 1404, 1340, 1297, 1249, 1159, 1138 , 1053, 989, 957, $840 \mathrm{~cm}^{-1}$. TOF ES-HRMS m/z: (M-H) found 223.1156, calc for $\mathrm{C}_{12} \mathrm{H}_{19} \mathrm{O}_{2} \mathrm{Si} 223.1154$.

\section{2-Methylene-5-phenyl-bicyclo[2.2.1]heptan-7-one [14]}

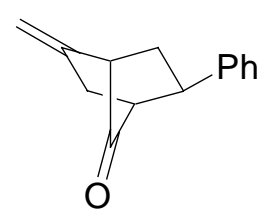

In a glovebox, the phenyl-substituted bridgehead allylsilane (50 $\mathrm{mg}, 0.174 \mathrm{mmol})$ was dissolved in THF (10 mL) and TASF (53 mg, $0.191 \mathrm{mmol})$ was added in one portion. The reaction instantly became yellow and was filtered through a plug of $\mathrm{SiO}_{2}$. The filtrate was concentrated to a yellow oil and characterized crude. Rf 0.57 (90:10 
hexanes:EtOAc). ${ }^{1} \mathrm{H}$ NMR (300 MHz, $\left.\mathrm{CDCl}_{3}\right) 7.29$ (m, $\left.5 \mathrm{H}\right), 5.08(\mathrm{~s}, 1 \mathrm{H}), 4.83(\mathrm{~s}, 1 \mathrm{H})$, $3.62(\mathrm{dd}, J=4.82 \mathrm{~Hz}, 1 \mathrm{H}), 2.75(\mathrm{~d}, J=4.53 \mathrm{~Hz}, 1 \mathrm{H}), 2.36-2.52(\mathrm{~m}, 4 \mathrm{H}), 2.39(\mathrm{dd}, J=$ 12.6, $5.9 \mathrm{~Hz}, 1 \mathrm{H})$. IR 1728. HRMS EI [M+] found 198.1039, calculated for $\mathrm{C}_{14} \mathrm{H}_{14} \mathrm{O}$ 198.1045.

\section{4-(1-Hydroxy-2,2-dimethyl-propyl)-5-methylene-2-phenyl-cyclohexane carboxylic acid [16a]}

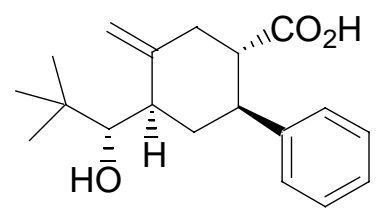

In a 2-neck schlenck flask was combined $325 \mathrm{mg}(1.65 \mathrm{mmol})$ of 2,6-di-tert-butyl-4methylpyridine and $315 \mathrm{mg}(1.65 \mathrm{mmol})$ of $\mathrm{TiCl}_{4}$ using glovebox techniques. Dichloromethane $(10 \mathrm{~mL})$ was added, and the solution was stirred magnetically and cooled in a dry ice-acetone bath. Pivaldehyde $(0.180 \mathrm{~mL}, 1.65 \mathrm{mmol})$ was added neat and the reaction mixture became green and cloudy. After stirring for 5 min with dry iceacetone cooling, $4 \mathrm{~mL}$ of a solution of the allylsilane $(444 \mathrm{mg}, 1.55 \mathrm{mmol})$ in dichloromethane was added and the reaction mixture immediately became clear and deep red. The reaction mixture warmed to RT overnight, and was then quenched by pouring the reaction mixture into a separatory funnel containing saturated aqueous $\mathrm{NaHCO}_{3}$. The aqueous layer was then made acidic with $2 \mathrm{~N} \mathrm{HCl}$, and the product was extracted 3 times with $\mathrm{CHCl}_{3}$ and once with EtOAc. The combined organic layer was dried over sodium sulfate, and the solvents were removed in vacuo. The residue was purified by flash chromatography on silica gel using a gradient of EtOAc in hexanes $(20: 80-50: 50)$ to 
give the product as $234 \mathrm{mg}$ of a slightly yellow oil that crystallized upon standing. Yield: $0.234 \mathrm{~g}(50 \%) . \mathrm{Mp}: 128.8-133.3{ }^{\circ} \mathrm{C} .{ }^{1} \mathrm{H}$ NMR $\left(500 \mathrm{MHz}, \mathrm{DCCl}_{3}\right): \delta$ 7.21-7.26 (m, 2H), 7.14-7.19 (m, 3H), $4.93(\mathrm{~d}, J=5.9 \mathrm{~Hz}, 2 \mathrm{H}), 3.75(\mathrm{~s}, 1 \mathrm{H}), 3.03(\operatorname{app} \mathrm{td}, J=12.5,3.5 \mathrm{~Hz}$, 1H), 2.64-2.72 (m, 2H), $2.45(\operatorname{app~d}, J=11.9 \mathrm{~Hz}, 1 \mathrm{H}), 2.38(\mathrm{t}, J=13.3 \mathrm{~Hz}, 1 \mathrm{H}), 2.01-$ $2.08(\mathrm{~m}, 1 \mathrm{H}), 1.60(\mathrm{qrt}, J=12.8 \mathrm{~Hz}, 1 \mathrm{H}), 0.93(\mathrm{~s}, 9 \mathrm{H}) .{ }^{13} \mathrm{C} \mathrm{NMR}\left(125 \mathrm{MHz}, \mathrm{DCCl}_{3}\right): \delta$ 179.6, 148.8, 143.8, 128.9, 127.8, 127.1, 108.1, 78.0, 51.7, 46.6, 43.7, 40.7, 36.20, 36.16, 27.2. IR $\left(\mathrm{KBr} \mathrm{cm}^{-1}\right)$ : 3431, 3031, 2952, 2891, 2639, 1709, 1654, 1458, 1363, 1309, $1282,1253,1234,1152,1082,980,905,769,698$. TOF ES-HRMS $m / z:(\mathrm{M}+\mathrm{Na})$ found 325.1784, calc for $\mathrm{C}_{19} \mathrm{H}_{26} \mathrm{O}_{3} \mathrm{Na} 325.1780$.

\section{4-(1-Hydroxy-2-methyl-propyl)-5-methylene-2-phenyl-}

\section{cyclohexanecarboxylic acid [16b]}

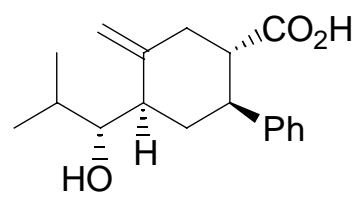

In a $25 \mathrm{~mL}$ Schlenck flask was combined $\mathrm{TiCl}_{4}(168 \mathrm{mg}, 0.88 \mathrm{mmol})$ and 4-methyl-2,6di-tert-butylpyridine (166 mg, $81 \mathrm{mmol}$ ) in $5 \mathrm{~mL}$ of dry $\mathrm{CH}_{2} \mathrm{Cl}_{2}$. This mixture was magnetically stirred under $\mathrm{N}_{2}$ and cooled in a dry ice-acetone bath. Freshly distilled isobutyraldehyde ( $80 \mu \mathrm{L}, 63 \mathrm{mg}, 0.87 \mathrm{mmol})$ was added. Stirring was continued and the reaction mixture turned grey-green and cloudy. After $5 \mathrm{~min}$, a solution of the allylsilane 
(200 $\mathrm{mg}, 0.7 \mathrm{mmol}$ ) in $2 \mathrm{~mL}$ of $\mathrm{CH}_{2} \mathrm{Cl}_{2}$ was added in a steady stream and the reaction was allowed to warm to rt. After stirring for $2 \mathrm{~d}$, the reaction mixture was quenched with water and poured into a separatory funnel. The aqueous layer was made acidic with $2 \mathrm{~N}$ $\mathrm{HCl}$. The organic layer was then separated, and the aqueous layer was extracted 3 times with EtOAc $(3 \times 15 \mathrm{~mL})$. The combined organic layer was dried over $\mathrm{Na}_{2} \mathrm{SO}_{4}$, filtered, and concentrated in vacuo. The residue was triturated with hexanes and filtered. The solids were washed with hexanes, and then were dissolved in EtOAc. The solvents were removed in vacuo to give the product as a white powder.

Yield: $0.149 \mathrm{~g}(74 \%)$. Mp: 182.8-185.0 ${ }^{\circ} \mathrm{C} .{ }^{1} \mathrm{H}$ NMR (500 MHz, DMSO- $\left.d 6\right): \delta 11.8-$ 12.2 (s.br., $1 \mathrm{H}), 7.14-7.29$ (m, 5 H), 4.91 (s, $1 \mathrm{H}), 4.79$ (s, $1 \mathrm{H}), 4.27$ (d, J= 5.9 Hz, $1 \mathrm{H}$ ), 2.95 (app. td, $J=12,3.4 \mathrm{~Hz}, 1 \mathrm{H}), 2.52-2.59$ (m, $2 \mathrm{H}), 2.20-2.30$ (m, $2 \mathrm{H}), 1.91$ (dt, $J=$ 13.2, $3.4 \mathrm{~Hz}, 1 \mathrm{H}$ ), 1.71 (sext., $J=6.6 \mathrm{~Hz}, 1 \mathrm{H}$ ), 1.39 (qrt., $J=12.5 \mathrm{~Hz}, 1 \mathrm{H}$ ), 0.86 (app. d, $J=6.6 \mathrm{~Hz}, 6 \mathrm{H}) .{ }^{13} \mathrm{C}$ NMR (125 MHz, DMSO- $\left.d 6\right): \delta 175.2,147.8,144.4,128.3$, 127.3, 126.3, 107.9, 74.3, 50.7, 45.8, 44.1, 40.2, 35.6, 30.5, 20.0, 18.3. IR ( $\mathrm{KBr}$ pellet, $\left.\mathrm{cm}^{-1}\right): 3275,3076,3030,2963,2934,2907,2877,2630,2534,1676,1646,1292,1261$, 993, 977, 901, 702. ESI-HRMS m/z [M+Na] found 311.1628, calculated for $\mathrm{C}_{18} \mathrm{H}_{24} \mathrm{O}_{3} \mathrm{Na}$ 311.1623

\section{4-(1-Hydroxy-butyl)-5-methylene-2-phenyl-cylcohexanecarboxylic acid}

\section{[16c]}

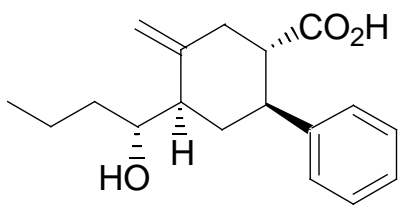


In a $25 \mathrm{~mL}$ Schlenck flask was combined $\mathrm{TiCl}_{4}(168 \mathrm{mg}, 0.88 \mathrm{mmol})$ and 2,6-di-tertbutyl-4-methylpyridine (166 mg, $81 \mathrm{mmol})$ in $5 \mathrm{~mL}$ of dry $\mathrm{CH}_{2} \mathrm{Cl}_{2}$. This mixture was magnetically stirred under $\mathrm{N}_{2}$ and cooled in a dry ice-acetone bath. Freshly distilled butyraldehyde (78 $\mu \mathrm{L}, 63 \mathrm{mg}, 0.87 \mathrm{mmol}$ ) was added. Stirring was continued and the reaction mixture turned reddish brown and cloudy. After $5 \mathrm{~min}$, a solution of the allylsilane (200 mg, $0.7 \mathrm{mmol}$ ) in $2 \mathrm{~mL}$ of $\mathrm{CH}_{2} \mathrm{Cl}_{2}$ was added in a rapid stream. The reaction mixture was allowed to warm to RT and was stirred for $2 \mathrm{~d}$. The reaction mixture was then quenched with water and poured into a separatory funnel. The aqueous layer was made acidic with $2 \mathrm{~N} \mathrm{HCl}$. The organic layer was then separated, and the aqueous layer was extracted with EtOAc $(3 \times 15 \mathrm{~mL})$. The combined organic layer was dried over $\mathrm{Na}_{2} \mathrm{SO}_{4}$, filtered, and the solvents removed in vacuo. The residue was purified by silica gel flash chromatography (hexanes: EtOAc, 2:1, Rf 0.1) to give the product as an off-white solid. Yield: $0.160 \mathrm{~g}(79 \%)$. Mp: 150.0-152.8 ${ }^{\circ} \mathrm{C} . \quad{ }^{1} \mathrm{H}$ NMR $(500 \mathrm{MHz}$, $\left.\mathrm{DCCl}_{3}\right): \delta$ 7.22-7.34 (m, 5H), $5.04(\mathrm{~s}, 1 \mathrm{H}), 4.94(\mathrm{~s}, 1 \mathrm{H}), 4.09-4.13(\mathrm{~m}, 1 \mathrm{H}), 3.03(\mathrm{td}, J=$ 12.0, $3.3 \mathrm{~Hz}, 1 \mathrm{H}$ ), 2.69-2.78 (m, 2H), 2.44 (t, $J=12.8 \mathrm{~Hz}, 1 \mathrm{H}$ ), 2.23 (app. d, $J=12.0 \mathrm{~Hz}$, 1H), 2.09 (app. dt, $J=13.0,3.9 \mathrm{~Hz}, 1 \mathrm{H}), 1.49-1.66$ (m, 4H), 1.37-1.46 (m, 1H), 0.99 (t, $J$ $=6.8 \mathrm{~Hz}, 3 \mathrm{H}) .{ }^{13} \mathrm{C} \mathrm{NMR}\left(125 \mathrm{MHz}, \mathrm{DCCl}_{3}\right): \delta 179.5,146.8,143.3,128.6,127.4,126.9$, 108.5, 70.9, 50.8, 46.8, 46.1, 40.1, 37.4, 34.0, 19.6, 14.2. IR (KBr pellet, $\left.\mathrm{cm}^{-1}\right)$ : 3265, 3078, 3065, 3029, 2957, 2934, 2907, 2873, 2862, 2546, 1674, 1648, 1297, 700. ESIHRMS m/z [M+Na] $]^{+}$found 311.1625, calculated for $\mathrm{C}_{18} \mathrm{H}_{24} \mathrm{O}_{3} \mathrm{Na} 311.1623$. 


\section{4-[Hydroxy-(3-nitro-phenyl)-methyl]-5-methylene-2-phenyl-}

\section{cyclohexanecarboxylic acid [16d]}

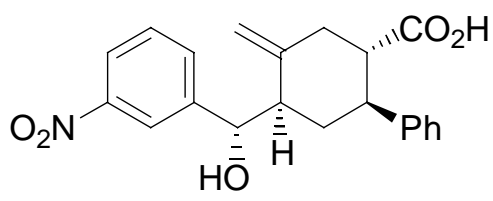

In a $25 \mathrm{~mL}$ schlenk flask was combined $\mathrm{TiCl}_{4}(168 \mathrm{mg}, 0.89 \mathrm{mmol})$ and 2,6-di-tert-butyl4-methylpyridine $(161 \mathrm{mg}, 0.78 \mathrm{mmol})$ under $\mathrm{N}_{2}$. The solids were dissolved in $5 \mathrm{~mL}$ of $\mathrm{CH}_{2} \mathrm{Cl}_{2}$ and the magnetically stirred solution was cooled with a dry ice-acetone bath. $m$ Nitrobenzaldehyde (132 mg, $0.87 \mathrm{mmol})$ was added in one portion, and the solution was allowed to warm to RT to dissolve the aldehyde. The solution was re-cooled in the dry ice-acetone bath and after $5 \mathrm{~min}$, the allylsilane $(200 \mathrm{mg}, 0.70 \mathrm{mmol})$ was added as a solution in $2 \mathrm{~mL}$ of $\mathrm{CH}_{2} \mathrm{Cl}_{2}$. The mixture was allowed to slowly warm to $\mathrm{RT}$ and was stirred for $48 \mathrm{~h}$. The reaction mixture was then quenched with water and poured into a separatory funnel. The organic layer was then separated, and the aqueous layer was extracted with EtOAc $(3 \times 15 \mathrm{~mL})$. The combined organic layer was dried over $\mathrm{Na}_{2} \mathrm{SO}_{4}$, filtered, and the solvents removed in vacuo. The residue was purified by $\mathrm{SiO}_{2}$ flash chromatography (hexanes: EtOAc, 5:1 to 0:1) to give the product as an off-white solid. Yield: $0.172 \mathrm{~g}(67 \%) . \quad \mathrm{Mp}: 187.8-189.1{ }^{\circ} \mathrm{C} .{ }^{1} \mathrm{H}$ NMR (500 MHz, DMSO-d6): $\delta 11.96$ (s.br., 1H), 8.19 (s.br., 1H), 8.07 (dd, $J=8.1,1.9 \mathrm{~Hz}, 1 \mathrm{H}), 7.82$ (d, J = $7.8 \mathrm{~Hz}, 1 \mathrm{H}), 7.60$ 
(t, $J=8.0 \mathrm{~Hz}, 1 \mathrm{H}), 7.11-7.24$ (m, 5H), 5.51 (d.br., $J=5.1 \mathrm{~Hz}, 1 \mathrm{H}), 5.14$ (s, 1H), 4.99 (d, $J$ $=6.8 \mathrm{~Hz}, 2 \mathrm{H}), 2.82(\mathrm{td}, J=11.6,4.2 \mathrm{~Hz}, 1 \mathrm{H}), 2.51-2.60(\mathrm{~m}, 3 \mathrm{H}), 2.32(\mathrm{t}, J=12.4 \mathrm{~Hz}$, 1H), 1.49-1.62 (m, 2H). ${ }^{13} \mathrm{C}$ NMR (125 MHz, $\left.\mathrm{DCCl}_{3}\right): \delta 174.9,147.9,147.7,146.5$, 144.0, 133.0, 129.4, 128.2, 127.3, 126.3, 121.6, 120.8, 108.9, 70.5, 50.6, 48.0, 45.6, 39.6,

33.4. IR ( $\mathrm{KBr}$ pellet, $\left.\mathrm{cm}^{-1}\right): 3442,3087,3030,2931,2868,1707,1648,1529,1350$, 1285, 1179, 1095, 904, 700. ESI-HRMS m/z $[\mathrm{M}+\mathrm{Na}]^{+}$found 390.1319, calculated for $\mathrm{C}_{21} \mathrm{H}_{21} \mathrm{NO}_{5} \mathrm{Na} 390.1317$.

\section{4-(1-Hydroxy-2-methyl-propyl)-3-methylene-cyclohexanecarboxylic}

\section{acid [17]}

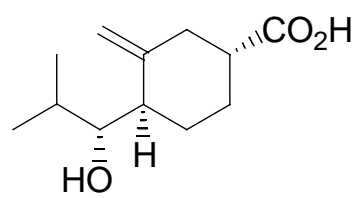

In a $25 \mathrm{~mL}$ schlenk flask was combined $\mathrm{TiCl}_{4}(209 \mathrm{mg}, 1.1 \mathrm{mmol})$ and 2,6-di-tert-butyl4-methylpyridine (205 mg, $1.0 \mathrm{mmol}$ ) under $\mathrm{N}_{2}$. The solids were dissolved in $2.5 \mathrm{~mL}$ $\mathrm{CH}_{2} \mathrm{Cl}_{2}$ and the magnetically stirred solution was cooled with a dry ice-acetone bath. Isobutyraldehyde (101 $\mu \mathrm{L}, 1.1 \mathrm{mmol})$ was added in one portion and the mixture became heterogeneous and orange. After $5 \mathrm{~min}$, a solution of the allylsilane (200 $\mathrm{mg}, 0.95 \mathrm{mmol})$ in $1 \mathrm{~mL} \mathrm{CH}_{2} \mathrm{Cl}_{2}$ was added. The flask that contained this solution was washed with $1 \mathrm{~mL}$ $\mathrm{CH}_{2} \mathrm{Cl}_{2}$ and this wash was added to the reaction flask. The reaction was slowly allowed 
to warm to RT and stirred for $48 \mathrm{~h}$. The reaction was quenched with $15 \mathrm{~mL}$ water and the layers were separated. The aqueous layer was extracted with three $15 \mathrm{~mL}$ portions of EtOAc. The combined organic layer was dried over $\mathrm{Na}_{2} \mathrm{SO}_{4}$, filtered, and the solvents were removed in vacuo. The viscous liquid residue was purified via $\mathrm{SiO}_{2}$ flash chromatography using a gradient from 2:1 to 1:1 hexanes:EtOAc to give the product as a yellow oil.

Yield: $0.156 \mathrm{~g}(77 \%) .{ }^{1} \mathrm{H}$ NMR $\left(500 \mathrm{MHz}, \mathrm{DCCl}_{3}\right): \delta 4.92(\mathrm{~s}, 1 \mathrm{H}), 4.81(\mathrm{~s}, 1 \mathrm{H}), 3.62-$ $3.65(\mathrm{~m}, 1 \mathrm{H}), 2.52-2.60(\mathrm{~m}, 1 \mathrm{H}), 2.45-2.53(\mathrm{~m}, 1 \mathrm{H}), 2.29(\mathrm{t}, J=11.5 \mathrm{~Hz}, 1 \mathrm{H}), 2.17-$ $2.24(\mathrm{~m}, 1 \mathrm{H}), 2.07-2.15(\mathrm{~m}, 1 \mathrm{H}), 1.87-1.94(\mathrm{~m}, 1 \mathrm{H}), 1.77-1.86(\mathrm{~m}, 1 \mathrm{H}), 1.62-1.73(\mathrm{~m}$, $1 \mathrm{H}), 1.42-1.54(\mathrm{~m}, 1 \mathrm{H}), 0.98(\mathrm{~d}, J=6.6 \mathrm{~Hz}, 3 \mathrm{H}), 0.90(\mathrm{~d}, J=6.6 \mathrm{~Hz}, 1 \mathrm{H}) .{ }^{13} \mathrm{C} \mathrm{NMR}$ (125 MHz, $\left.\mathrm{DCCl}_{3}\right): \delta 180.8,147.5,108.9,76.0,44.4,43.9,38.1,30.4,27.4,25.1,19.7$, 18.1. IR $\left(\mathrm{NaCl}\right.$ thin film, $\left.\mathrm{cm}^{-1}\right): 3423,3084,2962,2875,1706,1646,1449,1282,1227$, 1182, 1074, 974, 909, 734. TOF ES-HRMS $m / z:(\mathrm{M}+\mathrm{Na})$ found 235.1308, calc for $\mathrm{C}_{12} \mathrm{H}_{20} \mathrm{O}_{3} \mathrm{Na} 235.1310$.

\section{Competition study}

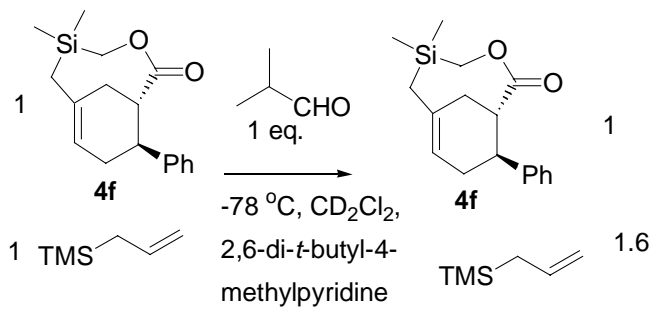

$\mathrm{TiCl}_{4}(42 \mathrm{mg}, 0.22 \mathrm{mmol})$ and 2,6-di-tert-butyl-4-methylpyridine (41 mg, $\left.0.20 \mathrm{mmol}\right)$ were combined in a $25 \mathrm{~mL}$ schlenk flask and dissolved in $0.75 \mathrm{~mL} \mathrm{CD}_{2} \mathrm{Cl}_{2}$. The mixture was cooled in a dry ice-acetone bath and isobutyraldehyde $(19 \mu \mathrm{L}, 0.21 \mathrm{mmol})$ was 
added via syringe. After $5 \mathrm{~min}$, a solution of $4 \mathbf{f}(60 \mathrm{mg}, 0.21 \mathrm{mmol})$ and trimethylallylsilane ( $33 \mu \mathrm{L}, 0.21 \mathrm{mmol}$ ) in $0.75 \mathrm{~mL}$ of $\mathrm{CD}_{2} \mathrm{Cl}_{2}$ was added rapidly. The mixture was stirred with dry ice-acetone bath cooling for $1.5 \mathrm{~h}$, and then allowed to warm to RT. The mixture was transferred to an NMR tube and analysis was performed immediately. The ${ }^{1} \mathrm{H}$ resonances of the remaining allylsilanes were quantified by integration of the alkene proton of the bridgehead allylsilane (a broad singlet at 5.50 $\mathrm{ppm}$ ) and one of the alkene protons of trimethylallylsilane (multiplet at $5.81 \mathrm{ppm}$ ).

X-ray Data Collection, Structure Solution and Refinement for 16c.

A colorless crystal of approximate dimensions $0.10 \times 0.28 \times 0.30 \mathrm{~mm}$ was mounted on a glass fiber and transferred to a Bruker CCD platform diffractometer. The SMART ${ }^{1}$ program package was used to determine the unit-cell parameters and for data collection $(25 \mathrm{sec} /$ frame scan time for a sphere of diffraction data). The raw frame data was processed using SAINT ${ }^{2}$ and $\mathrm{SADABS}^{3}$ to yield the reflection data file. Subsequent calculations were carried out using the SHELXTL ${ }^{4}$ program. The diffraction symmetry was $2 / m$ and the systematic absences were consistent with the centrosymmetric monoclinic space group $P 2_{1} / c$ which was later determined to be correct.

The structure was solved by direct methods and refined on $\mathrm{F}^{2}$ by full-matrix least-squares techniques. The analytical scattering factors ${ }^{5}$ for neutral atoms were used throughout the analysis. Hydrogen atoms were either located from a difference-Fourier map and refined $\left(\mathrm{x}, \mathrm{y}, \mathrm{Z}\right.$ and $\left.\mathrm{U}_{\mathrm{iso}}\right)$ or were included using a riding model. There was one-half molecule of hexane solvent present per formula unit. The solvent was located about an inversion center. It was necessary to constrain the thermal parameters and the carbon-carbon distances associated with the solvent molecule. Least-squares analysis yielded $\mathrm{wR} 2=$ 0.2243 and $\mathrm{Goof}=1.037$ for 216 variables refined against 3935 data. As a comparison for refinement on F, R1 $=0.0689$ for those 2793 data with $\mathrm{I}>2.0 \sigma(\mathrm{I})$. 
References.

1. SMART Software Users Guide, Version 5.1, Bruker Analytical X-Ray Systems, Inc.; Madison, WI 1999.

2. SAINT Software Users Guide, Version 6.0, Bruker Analytical X-Ray Systems, Inc.; Madison, WI 1999.

3. Sheldrick, G. M. SADABS, Version 2.10, Bruker Analytical X-Ray Systems, Inc.; Madison, WI 2002.

4. Sheldrick, G. M. SHELXTL Version 6.12, Bruker Analytical X-Ray Systems, Inc.; Madison, WI 2001.

5. International Tables for X-Ray Crystallography 1992, Vol. C., Dordrecht: Kluwer Academic Publishers.

Definitions:

$\mathrm{wR} 2=\left[\Sigma\left[\mathrm{w}\left(\mathrm{F}_{\mathrm{o}}^{2}-\mathrm{F}_{\mathrm{c}}\right)^{2}\right] / \Sigma\left[\mathrm{w}\left(\mathrm{F}_{\mathrm{o}}^{2}\right)^{2}\right]\right]^{1 / 2}$

$\mathrm{R} 1=\Sigma|| \mathrm{F}_{\mathrm{o}}|-| \mathrm{F}_{\mathrm{c}} \| / \Sigma\left|\mathrm{F}_{\mathrm{o}}\right|$

Goof $=\mathrm{S}=\left[\Sigma\left[\mathrm{w}\left(\mathrm{F}_{\mathrm{o}}{ }^{2}-\mathrm{F}_{\mathrm{c}}{ }^{2}\right)^{2}\right] /(\mathrm{n}-\mathrm{p})\right]^{1 / 2}$ where $\mathrm{n}$ is the number of reflections and $\mathrm{p}$ is the total number of parameters refined.

The thermal ellipsoid plot is shown at the $50 \%$ probability level. 


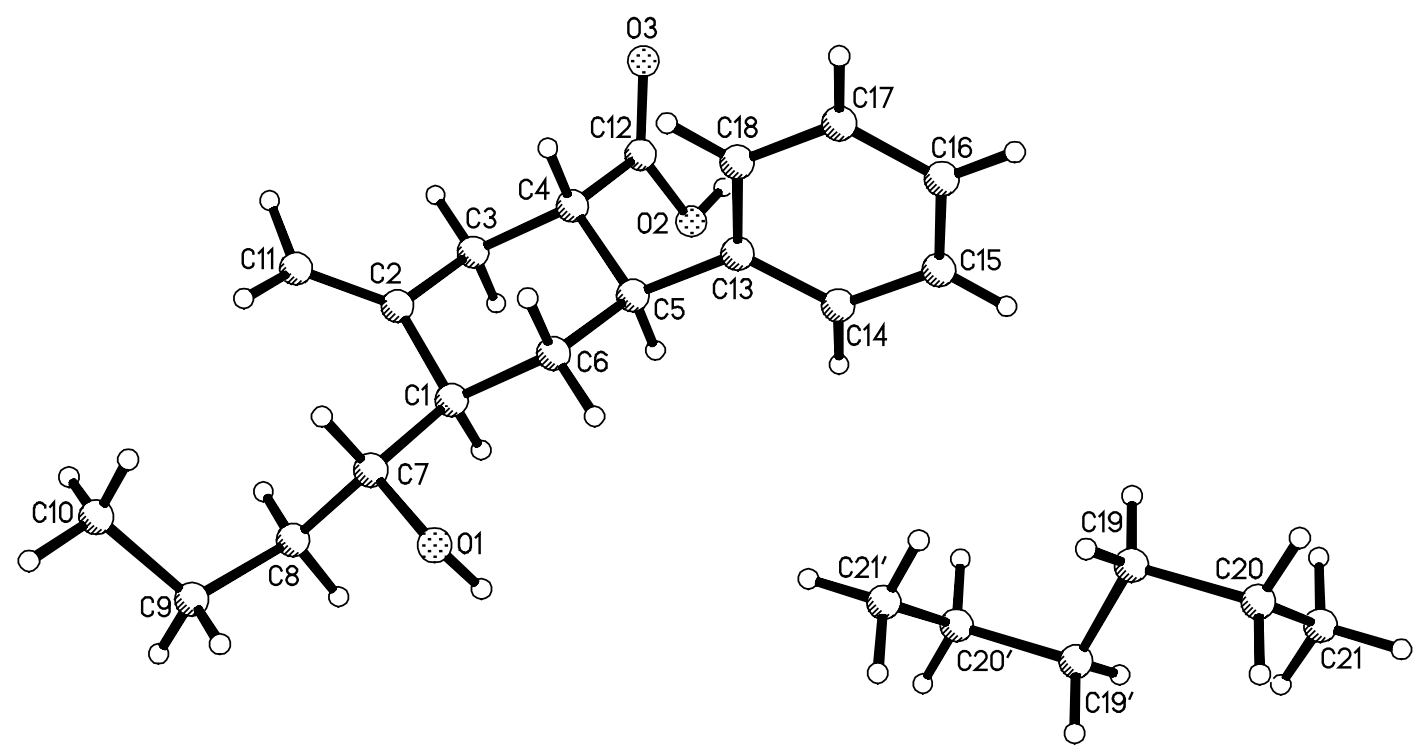




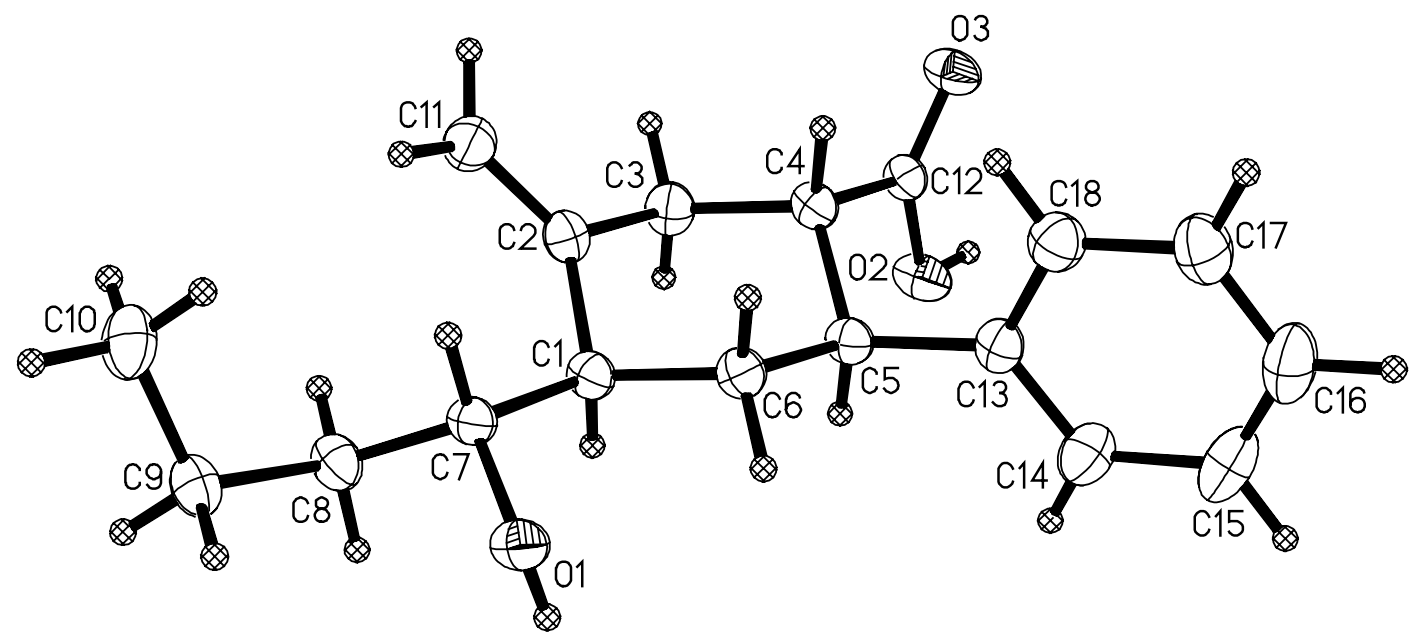

Table 1. Crystal data and structure refinement for $\mathbf{1 6 c}$.

Identification code

Empirical formula

Formula weight

Temperature

Wavelength

Crystal system

Space group

Unit cell dimensions

Volume

Z

Density (calculated)

Absorption coefficient

$\mathrm{F}(000)$

Crystal color

Crystal size

Theta range for data collection

Index ranges

Reflections collected kjs50 (Ryan Lauchli)

$\mathrm{C}_{18} \mathrm{H}_{24} \mathrm{O}_{3} \bullet 1 / 2\left(\mathrm{C}_{6} \mathrm{H}_{14}\right)$

331.46

158(2) K

$0.71073 \AA$

Monoclinic

$P 2{ }_{1} / c$

$a=6.0054(5) \AA \quad \alpha=90^{\circ}$.

$\mathrm{b}=20.4908(18) \AA \quad \beta=96.822(2)^{\circ}$.

$\mathrm{c}=15.7065(14) \AA \quad \gamma=90^{\circ}$.

1919.1(3) $\AA^{3}$

4

$1.147 \mathrm{Mg} / \mathrm{m}^{3}$

$0.075 \mathrm{~mm}^{-1}$

724

colorless

$0.30 \times 0.28 \times 0.10 \mathrm{~mm}^{3}$

1.64 to $26.37^{\circ}$.

$-7 \leq h \leq 7,-25 \leq k \leq 25,-19 \leq l \leq 18$

18745 
Independent reflections

Completeness to theta $=26.37^{\circ}$

Absorption correction

Max. and min. transmission

Refinement method

Data / restraints / parameters

Goodness-of-fit on $\mathrm{F}^{2}$
$3935[\mathrm{R}(\mathrm{int})=0.0430]$

$100.0 \%$

Semi-empirical from equivalents

0.9926 and 0.9779

Full-matrix least-squares on $\mathrm{F}^{2}$

3935 / 3 / 216

1.037

Final $\mathrm{R}$ indices [I>2sigma $(\mathrm{I})=2793$ data]

$\mathrm{R}$ indices (all data; 0.80)

$\mathrm{R} 1=0.0689, \mathrm{wR} 2=0.1967$

Largest diff. peak and hole
$\mathrm{R} 1=0.0980, \mathrm{wR} 2=0.2243$

0.894 and -0.635 e. $\AA^{-3}$ 
Table 2. Atomic coordinates ( $\mathrm{x} 10^{4}$ ) and equivalent isotropic displacement parameters $\left(\AA^{2} \times 10^{3}\right)$

for 16c. U(eq) is defined as one third of the trace of the orthogonalized $U^{i j}$ tensor.

\begin{tabular}{|c|c|c|c|c|}
\hline & $\mathrm{x}$ & $\mathrm{y}$ & $\mathrm{z}$ & $\mathrm{U}(\mathrm{eq})$ \\
\hline $\mathrm{O}(1)$ & $4205(3)$ & $2759(1)$ & $5107(1)$ & $26(1)$ \\
\hline $\mathrm{O}(2)$ & $-2644(3)$ & $2446(1)$ & $1353(1)$ & $30(1)$ \\
\hline $\mathrm{O}(3)$ & $-156(3)$ & $2288(1)$ & $429(1)$ & $29(1)$ \\
\hline $\mathrm{C}(1)$ & $2708(4)$ & $3050(1)$ & $3641(2)$ & $22(1)$ \\
\hline$C(2)$ & $3149(4)$ & $3395(1)$ & $2821(2)$ & $24(1)$ \\
\hline$C(3)$ & $1366(5)$ & $3260(1)$ & 2081(2) & $27(1)$ \\
\hline$C(4)$ & $1198(4)$ & $2519(1)$ & 1902(2) & $22(1)$ \\
\hline$C(5)$ & $757(4)$ & $2147(1)$ & $2715(2)$ & $22(1)$ \\
\hline$C(6)$ & $2583(4)$ & $2313(1)$ & $3458(2)$ & $23(1)$ \\
\hline$C(7)$ & $4380(4)$ & $3220(1)$ & $4425(2)$ & $22(1)$ \\
\hline $\mathrm{C}(8)$ & $4021(4)$ & $3910(1)$ & $4751(2)$ & $27(1)$ \\
\hline $\mathrm{C}(9)$ & $5875(5)$ & $4156(1)$ & $5424(2)$ & $28(1)$ \\
\hline$C(10)$ & $8053(5)$ & 4299(2) & $5064(2)$ & $35(1)$ \\
\hline $\mathrm{C}(11)$ & $4961(5)$ & $3737(2)$ & $2711(2)$ & $31(1)$ \\
\hline$C(12)$ & $-580(4)$ & 2399(1) & $1153(2)$ & $21(1)$ \\
\hline$C(13)$ & $599(4)$ & $1414(1)$ & $2578(2)$ & $24(1)$ \\
\hline$C(14)$ & $-1244(5)$ & $1069(2)$ & $2798(2)$ & $35(1)$ \\
\hline$C(15)$ & $-1384(6)$ & $396(2)$ & $2698(2)$ & $45(1)$ \\
\hline$C(16)$ & $319(6)$ & $58(2)$ & $2385(2)$ & $42(1)$ \\
\hline$C(17)$ & 2163(6) & $390(2)$ & $2169(2)$ & $37(1)$ \\
\hline $\mathrm{C}(18)$ & $2301(5)$ & $1062(1)$ & $2262(2)$ & $31(1)$ \\
\hline C(19) & $-4472(18)$ & $-277(3)$ & $4761(7)$ & $195(3)$ \\
\hline$C(20)$ & $-5286(15)$ & $-935(5)$ & $5085(8)$ & $195(3)$ \\
\hline $\mathrm{C}(21)$ & $-7861(15)$ & $-963(6)$ & 4919(8) & $195(3)$ \\
\hline
\end{tabular}


Table 3. Bond lengths $[\AA]$ and angles $\left[^{\circ}\right]$ for $\mathbf{1 6 c}$.

\begin{tabular}{|c|c|}
\hline $\mathrm{O}(1)-\mathrm{C}(7)$ & $1.442(3)$ \\
\hline $\mathrm{O}(2)-\mathrm{C}(12)$ & $1.318(3)$ \\
\hline $\mathrm{O}(3)-\mathrm{C}(12)$ & $1.215(3)$ \\
\hline$C(1)-C(2)$ & $1.520(4)$ \\
\hline $\mathrm{C}(1)-\mathrm{C}(7)$ & $1.533(3)$ \\
\hline$C(1)-C(6)$ & $1.538(4)$ \\
\hline $\mathrm{C}(2)-\mathrm{C}(11)$ & $1.323(4)$ \\
\hline$C(2)-C(3)$ & $1.509(4)$ \\
\hline $\mathrm{C}(3)-\mathrm{C}(4)$ & $1.544(4)$ \\
\hline$C(4)-C(12)$ & $1.513(3)$ \\
\hline $\mathrm{C}(4)-\mathrm{C}(5)$ & $1.537(4)$ \\
\hline$C(5)-C(13)$ & $1.518(4)$ \\
\hline$C(5)-C(6)$ & $1.542(3)$ \\
\hline$C(7)-C(8)$ & $1.528(4)$ \\
\hline$C(8)-C(9)$ & $1.528(4)$ \\
\hline C(9)-C(10) & $1.514(4)$ \\
\hline $\mathrm{C}(13)-\mathrm{C}(18)$ & $1.390(4)$ \\
\hline $\mathrm{C}(13)-\mathrm{C}(14)$ & $1.391(4)$ \\
\hline $\mathrm{C}(14)-\mathrm{C}(15)$ & $1.390(5)$ \\
\hline$C(15)-C(16)$ & $1.374(5)$ \\
\hline C(16)-C(17) & $1.376(5)$ \\
\hline $\mathrm{C}(17)-\mathrm{C}(18)$ & $1.386(4)$ \\
\hline C(19)-C(19)\#1 & $1.5395(10)$ \\
\hline $\mathrm{C}(19)-\mathrm{C}(20)$ & $1.5399(10)$ \\
\hline$C(20)-C(21)$ & $1.5388(10)$ \\
\hline$C(2)-C(1)-C(7)$ & $114.3(2)$ \\
\hline $\mathrm{C}(2)-\mathrm{C}(1)-\mathrm{C}(6)$ & $107.9(2)$ \\
\hline $\mathrm{C}(7)-\mathrm{C}(1)-\mathrm{C}(6)$ & $112.6(2)$ \\
\hline $\mathrm{C}(11)-\mathrm{C}(2)-\mathrm{C}(3)$ & $121.1(3)$ \\
\hline $\mathrm{C}(11)-\mathrm{C}(2)-\mathrm{C}(1)$ & $125.8(2)$ \\
\hline $\mathrm{C}(3)-\mathrm{C}(2)-\mathrm{C}(1)$ & $112.8(2)$ \\
\hline $\mathrm{C}(2)-\mathrm{C}(3)-\mathrm{C}(4)$ & $110.2(2)$ \\
\hline$C(12)-C(4)-C(5)$ & $113.0(2)$ \\
\hline
\end{tabular}




$\begin{array}{ll}\mathrm{C}(12)-\mathrm{C}(4)-\mathrm{C}(3) & 109.1(2) \\ \mathrm{C}(5)-\mathrm{C}(4)-\mathrm{C}(3) & 110.5(2) \\ \mathrm{C}(13)-\mathrm{C}(5)-\mathrm{C}(4) & 112.8(2) \\ \mathrm{C}(13)-\mathrm{C}(5)-\mathrm{C}(6) & 110.6(2) \\ \mathrm{C}(4)-\mathrm{C}(5)-\mathrm{C}(6) & 110.0(2) \\ \mathrm{C}(1)-\mathrm{C}(6)-\mathrm{C}(5) & 111.9(2) \\ \mathrm{O}(1)-\mathrm{C}(7)-\mathrm{C}(8) & 109.4(2) \\ \mathrm{O}(1)-\mathrm{C}(7)-\mathrm{C}(1) & 110.5(2) \\ \mathrm{C}(8)-\mathrm{C}(7)-\mathrm{C}(1) & 111.9(2) \\ \mathrm{C}(9)-\mathrm{C}(8)-\mathrm{C}(7) & 114.7(2) \\ \mathrm{C}(10)-\mathrm{C}(9)-\mathrm{C}(8) & 113.3(2) \\ \mathrm{O}(3)-\mathrm{C}(12)-\mathrm{O}(2) & 123.0(2) \\ \mathrm{O}(3)-\mathrm{C}(12)-\mathrm{C}(4) & 123.4(2) \\ \mathrm{O}(2)-\mathrm{C}(12)-\mathrm{C}(4) & 113.6(2) \\ \mathrm{C}(18)-\mathrm{C}(13)-\mathrm{C}(14) & 117.7(3) \\ \mathrm{C}(18)-\mathrm{C}(13)-\mathrm{C}(5) & 121.9(2) \\ \mathrm{C}(14)-\mathrm{C}(13)-\mathrm{C}(5) & 120.4(3) \\ \mathrm{C}(15)-\mathrm{C}(14)-\mathrm{C}(13) & 121.1(3) \\ \mathrm{C}(16)-\mathrm{C}(15)-\mathrm{C}(14) & 120.2(3) \\ \mathrm{C}(15)-\mathrm{C}(16)-\mathrm{C}(17) & 119.6(3) \\ \mathrm{C}(16)-\mathrm{C}(17)-\mathrm{C}(18) & 120.3(3) \\ \mathrm{C}(17)-\mathrm{C}(18)-\mathrm{C}(13) & 121.1(3) \\ \mathrm{C}(19) \# 1-\mathrm{C}(19)-\mathrm{C}(20) & 108.6(10) \\ \mathrm{C}(21)-\mathrm{C}(20)-\mathrm{C}(19) & 109.2(9) \\ & \end{array}$

Symmetry transformations used to generate equivalent atoms:

\#1 -x-1,-y,-z+1 
Table 4. Anisotropic displacement parameters $\left(\AA^{2} \times 10^{3}\right)$ for $\mathbf{1 6 c}$. The anisotropic displacement factor exponent takes the form: $-2 \pi^{2}\left[h^{2} a^{* 2} U^{11}+\ldots+2 h k a^{*} b^{*} U^{12}\right]$

\begin{tabular}{|c|c|c|c|c|c|c|}
\hline & $\mathrm{U}^{11}$ & $\mathrm{U}^{22}$ & $\mathrm{U}^{33}$ & $\mathrm{U}^{23}$ & $\mathrm{U}^{13}$ & $\mathrm{U}^{12}$ \\
\hline $\mathrm{O}(1)$ & $19(1)$ & $37(1)$ & $19(1)$ & $1(1)$ & $-1(1)$ & $-2(1)$ \\
\hline $\mathrm{O}(2)$ & $18(1)$ & $49(1)$ & $22(1)$ & $-5(1)$ & $-2(1)$ & $3(1)$ \\
\hline $\mathrm{O}(3)$ & $21(1)$ & $45(1)$ & $21(1)$ & $-6(1)$ & $0(1)$ & $0(1)$ \\
\hline $\mathrm{C}(1)$ & $18(1)$ & $26(1)$ & $21(1)$ & $-2(1)$ & $0(1)$ & $0(1)$ \\
\hline $\mathrm{C}(2)$ & $26(1)$ & $23(1)$ & $23(1)$ & $-2(1)$ & $0(1)$ & $1(1)$ \\
\hline $\mathrm{C}(3)$ & $30(1)$ & $26(1)$ & $22(1)$ & $3(1)$ & $-3(1)$ & $0(1)$ \\
\hline$C(4)$ & $17(1)$ & $26(1)$ & $21(1)$ & $-3(1)$ & $-1(1)$ & $1(1)$ \\
\hline$C(5)$ & $19(1)$ & $26(1)$ & $19(1)$ & $-1(1)$ & $-1(1)$ & $0(1)$ \\
\hline$C(6)$ & $21(1)$ & $26(1)$ & $20(1)$ & $0(1)$ & $-2(1)$ & $-1(1)$ \\
\hline$C(7)$ & $18(1)$ & $27(1)$ & $19(1)$ & $-1(1)$ & $1(1)$ & $-1(1)$ \\
\hline $\mathrm{C}(8)$ & $20(1)$ & $32(2)$ & $27(1)$ & $-6(1)$ & $-1(1)$ & $1(1)$ \\
\hline $\mathrm{C}(9)$ & $28(1)$ & $29(1)$ & $27(1)$ & $-6(1)$ & $-2(1)$ & $0(1)$ \\
\hline$C(10)$ & $26(2)$ & $35(2)$ & $42(2)$ & $-6(1)$ & $-5(1)$ & $-3(1)$ \\
\hline $\mathrm{C}(11)$ & $34(2)$ & $32(2)$ & $26(2)$ & 1(1) & $2(1)$ & $-6(1)$ \\
\hline$C(12)$ & $20(1)$ & $23(1)$ & $20(1)$ & $-1(1)$ & $0(1)$ & 1(1) \\
\hline $\mathrm{C}(13)$ & $24(1)$ & $25(1)$ & $20(1)$ & 1(1) & $-5(1)$ & $-2(1)$ \\
\hline $\mathrm{C}(14)$ & $30(2)$ & $32(2)$ & $43(2)$ & $2(1)$ & $5(1)$ & $-4(1)$ \\
\hline$C(15)$ & $42(2)$ & $33(2)$ & $57(2)$ & $8(2)$ & $1(2)$ & $-13(1)$ \\
\hline$C(16)$ & $53(2)$ & $24(2)$ & $46(2)$ & $3(1)$ & $-5(2)$ & $-4(1)$ \\
\hline $\mathrm{C}(17)$ & $43(2)$ & $28(2)$ & $38(2)$ & $-2(1)$ & $2(1)$ & $4(1)$ \\
\hline $\mathrm{C}(18)$ & $30(2)$ & $31(2)$ & $31(2)$ & $0(1)$ & $3(1)$ & $-1(1)$ \\
\hline
\end{tabular}


Table 5. Hydrogen coordinates $\left(\mathrm{x} 10^{4}\right)$ and isotropic displacement parameters $\left(\AA^{2} \mathrm{x} 10\right.$ 3) for $16 c$.

\begin{tabular}{|c|c|c|c|c|}
\hline & $\mathrm{x}$ & $\mathrm{y}$ & $\mathrm{Z}$ & $\mathrm{U}(\mathrm{eq})$ \\
\hline $\mathrm{H}(1 \mathrm{~B})$ & 1190 & 3191 & 3772 & 26 \\
\hline $\mathrm{H}(3 \mathrm{~A})$ & 1739 & 3490 & 1563 & 32 \\
\hline $\mathrm{H}(3 \mathrm{~B})$ & -98 & 3425 & 2220 & 32 \\
\hline $\mathrm{H}(4 \mathrm{~A})$ & 2670 & 2369 & 1735 & 26 \\
\hline $\mathrm{H}(5 \mathrm{~A})$ & -714 & 2300 & 2880 & 26 \\
\hline $\mathrm{H}(6 \mathrm{~A})$ & 2259 & 2080 & 3981 & 27 \\
\hline $\mathrm{H}(6 \mathrm{~B})$ & 4055 & 2160 & 3312 & 27 \\
\hline $\mathrm{H}(7 \mathrm{~A})$ & 5930 & 3192 & 4254 & 26 \\
\hline $\mathrm{H}(8 \mathrm{~A})$ & 3891 & 4213 & 4256 & 32 \\
\hline $\mathrm{H}(8 \mathrm{~B})$ & 2580 & 3921 & 4998 & 32 \\
\hline $\mathrm{H}(9 \mathrm{~A})$ & 5354 & 4559 & 5687 & 34 \\
\hline $\mathrm{H}(9 \mathrm{~B})$ & 6156 & 3824 & 5882 & 34 \\
\hline $\mathrm{H}(10 \mathrm{~A})$ & 9175 & 4451 & 5525 & 52 \\
\hline $\mathrm{H}(10 \mathrm{~B})$ & 7801 & 4637 & 4622 & 52 \\
\hline $\mathrm{H}(10 \mathrm{C})$ & 8594 & 3900 & 4810 & 52 \\
\hline $\mathrm{H}(14 \mathrm{~A})$ & -2427 & 1298 & 3019 & 42 \\
\hline $\mathrm{H}(15 \mathrm{~A})$ & -2661 & 169 & 2848 & 53 \\
\hline $\mathrm{H}(16 \mathrm{~A})$ & 224 & -403 & 2318 & 50 \\
\hline $\mathrm{H}(17 \mathrm{~A})$ & 3348 & 157 & 1956 & 44 \\
\hline $\mathrm{H}(18 \mathrm{~A})$ & 3579 & 1285 & 2107 & 37 \\
\hline $\mathrm{H}(1)$ & $2770(70)$ & $2760(17)$ & $5240(20)$ & $41(9)$ \\
\hline $\mathrm{H}(2)$ & $-3570(60)$ & $2390(17)$ & $890(20)$ & $41(9)$ \\
\hline $\mathrm{H}(11 \mathrm{~A})$ & $5310(60)$ & $3888(17)$ & $2140(20)$ & $41(9)$ \\
\hline $\mathrm{H}(11 \mathrm{~B})$ & $6170(50)$ & $3798(16)$ & $3160(20)$ & $31(8)$ \\
\hline $\mathrm{H}(19 \mathrm{~A})$ & -2817 & -252 & 4868 & 234 \\
\hline $\mathrm{H}(19 \mathrm{~B})$ & -4923 & -236 & 4136 & 234 \\
\hline $\mathrm{H}(20 \mathrm{~A})$ & -4630 & -1298 & 4783 & 234 \\
\hline
\end{tabular}




\begin{tabular}{lrrrr}
$\mathrm{H}(20 \mathrm{~B})$ & -4794 & -980 & 5707 & 234 \\
$\mathrm{H}(21 \mathrm{~A})$ & -8386 & -1380 & 5129 & 293 \\
$\mathrm{H}(21 \mathrm{~B})$ & -8337 & -925 & 4303 & 293 \\
$\mathrm{H}(21 \mathrm{C})$ & -8501 & -603 & 5221 & 293 \\
\hline
\end{tabular}


Table 6. Torsion angles $\left[{ }^{\circ}\right]$ for $\mathbf{1 6 c}$.

\begin{tabular}{lc}
\hline $\mathrm{C}(7)-\mathrm{C}(1)-\mathrm{C}(2)-\mathrm{C}(11)$ & $10.0(4)$ \\
$\mathrm{C}(6)-\mathrm{C}(1)-\mathrm{C}(2)-\mathrm{C}(11)$ & $-116.1(3)$ \\
$\mathrm{C}(7)-\mathrm{C}(1)-\mathrm{C}(2)-\mathrm{C}(3)$ & $-175.3(2)$ \\
$\mathrm{C}(6)-\mathrm{C}(1)-\mathrm{C}(2)-\mathrm{C}(3)$ & $58.6(3)$ \\
$\mathrm{C}(11)-\mathrm{C}(2)-\mathrm{C}(3)-\mathrm{C}(4)$ & $116.3(3)$ \\
$\mathrm{C}(1)-\mathrm{C}(2)-\mathrm{C}(3)-\mathrm{C}(4)$ & $-58.7(3)$ \\
$\mathrm{C}(2)-\mathrm{C}(3)-\mathrm{C}(4)-\mathrm{C}(12)$ & $-179.4(2)$ \\
$\mathrm{C}(2)-\mathrm{C}(3)-\mathrm{C}(4)-\mathrm{C}(5)$ & $55.9(3)$ \\
$\mathrm{C}(12)-\mathrm{C}(4)-\mathrm{C}(5)-\mathrm{C}(13)$ & $58.1(3)$ \\
$\mathrm{C}(3)-\mathrm{C}(4)-\mathrm{C}(5)-\mathrm{C}(13)$ & $-179.4(2)$ \\
$\mathrm{C}(12)-\mathrm{C}(4)-\mathrm{C}(5)-\mathrm{C}(6)$ & $-177.9(2)$ \\
$\mathrm{C}(3)-\mathrm{C}(4)-\mathrm{C}(5)-\mathrm{C}(6)$ & $-55.4(3)$ \\
$\mathrm{C}(2)-\mathrm{C}(1)-\mathrm{C}(6)-\mathrm{C}(5)$ & $-57.6(3)$ \\
$\mathrm{C}(7)-\mathrm{C}(1)-\mathrm{C}(6)-\mathrm{C}(5)$ & $175.3(2)$ \\
$\mathrm{C}(13)-\mathrm{C}(5)-\mathrm{C}(6)-\mathrm{C}(1)$ & $-177.3(2)$ \\
$\mathrm{C}(4)-\mathrm{C}(5)-\mathrm{C}(6)-\mathrm{C}(1)$ & $57.5(3)$ \\
$\mathrm{C}(2)-\mathrm{C}(1)-\mathrm{C}(7)-\mathrm{O}(1)$ & $-165.3(2)$ \\
$\mathrm{C}(6)-\mathrm{C}(1)-\mathrm{C}(7)-\mathrm{O}(1)$ & $-41.7(3)$ \\
$\mathrm{C}(2)-\mathrm{C}(1)-\mathrm{C}(7)-\mathrm{C}(8)$ & $72.6(3)$ \\
$\mathrm{C}(6)-\mathrm{C}(1)-\mathrm{C}(7)-\mathrm{C}(8)$ & $-163.8(2)$ \\
$\mathrm{O}(1)-\mathrm{C}(7)-\mathrm{C}(8)-\mathrm{C}(9)$ & $67.7(3)$ \\
$\mathrm{C}(1)-\mathrm{C}(7)-\mathrm{C}(8)-\mathrm{C}(9)$ & $-169.5(2)$ \\
$\mathrm{C}(7)-\mathrm{C}(8)-\mathrm{C}(9)-\mathrm{C}(10)$ & $70.8(3)$ \\
$\mathrm{C}(5)-\mathrm{C}(4)-\mathrm{C}(12)-\mathrm{O}(3)$ & $-135.2(3)$ \\
$\mathrm{C}(3)-\mathrm{C}(4)-\mathrm{C}(12)-\mathrm{O}(3)$ & $101.6(3)$ \\
$\mathrm{C}(5)-\mathrm{C}(4)-\mathrm{C}(12)-\mathrm{O}(2)$ & $46.8(3)$ \\
$\mathrm{C}(3)-\mathrm{C}(4)-\mathrm{C}(12)-\mathrm{O}(2)$ & $-76.4(3)$ \\
$\mathrm{C}(4)-\mathrm{C}(5)-\mathrm{C}(13)-\mathrm{C}(18)$ & $54.9(3)$ \\
$\mathrm{C}(6)-\mathrm{C}(5)-\mathrm{C}(13)-\mathrm{C}(18)$ & $-68.8(3)$ \\
$\mathrm{C}(4)-\mathrm{C}(5)-\mathrm{C}(13)-\mathrm{C}(14)$ & $-127.4(3)$ \\
$\mathrm{C}(6)-\mathrm{C}(5)-\mathrm{C}(13)-\mathrm{C}(14)$ & $109.0(3)$ \\
$\mathrm{C}(18)-\mathrm{C}(13)-\mathrm{C}(14)-\mathrm{C}(15)$ & $-0.4(4)$ \\
$\mathrm{C}(5)-\mathrm{C}(13)-\mathrm{C}(14)-\mathrm{C}(15)$ & $-178.2(3)$ \\
$\mathrm{C}(13)-\mathrm{C}(14)-\mathrm{C}(15)-\mathrm{C}(16)$ & \\
& \\
&
\end{tabular}




$\begin{array}{lc}\mathrm{C}(14)-\mathrm{C}(15)-\mathrm{C}(16)-\mathrm{C}(17) & -0.1(5) \\ \mathrm{C}(15)-\mathrm{C}(16)-\mathrm{C}(17)-\mathrm{C}(18) & -0.4(5) \\ \mathrm{C}(16)-\mathrm{C}(17)-\mathrm{C}(18)-\mathrm{C}(13) & 0.4(5) \\ \mathrm{C}(14)-\mathrm{C}(13)-\mathrm{C}(18)-\mathrm{C}(17) & 0.0(4) \\ \mathrm{C}(5)-\mathrm{C}(13)-\mathrm{C}(18)-\mathrm{C}(17) & 177.8(3) \\ \mathrm{C}(19) \# 1-\mathrm{C}(19)-\mathrm{C}(20)-\mathrm{C}(21) & 59.2(15)\end{array}$

Symmetry transformations used to generate equivalent atoms:

$\# 1-\mathrm{x}-1,-\mathrm{y},-\mathrm{z}+1$

X-ray Data Collection, Structure Solution and Refinement for $\mathbf{4 f}$.

A colorless crystal of approximate dimensions $0.23 \times 0.50 \times 0.50 \mathrm{~mm}$ was mounted on a glass fiber and transferred to a Siemens P4 diffractometer. The XSCANS ${ }^{1}$ program package was used to determine the Laue symmetry, crystal class, unit-cell parameters and for data collection. Intensity data were collected at $296 \mathrm{~K}$ using a $2 \theta / \omega$ scan technique with MoK $\alpha$ radiation. The raw data were processed with a local version of CARESS ${ }^{2}$ which employs a modified version of the Lehman-Larsen algorithm to obtain intensities and standard deviations from the measured 96-step profiles. Subsequent calculations were carried out using the SHELXTL ${ }^{3}$ program. All data were corrected for Lorentz and polarization effects and placed on an approximately absolute scale. The diffraction symmetry was $\mathrm{mmm}$ and the systematic absences were consistent with space group Pca2 $2_{1}$ which was later determined to be correct.

The structure was solved by direct methods and refined on $\mathrm{F}^{2}$ by full-matrix least-squares techniques. The analytical scattering factors ${ }^{4}$ for neutral atoms were used throughout the analysis. Hydrogen atoms were included using a riding model. At convergence, wR2 = 0.0873 and $\mathrm{GOF}=1.074$ for 182 variables refined against 1272 data $(0.93 \AA)$. As a comparison for refinement on $\mathrm{F}, \mathrm{R} 1=0.0356$ for those 1101 data with $\mathrm{I}>2.0 \sigma(\mathrm{I})$. The absolute structure was assigned by refinement of the Flack ${ }^{5}$ parameter. 
References.

6. XSCANS Software Users Guide, Version 2.1, Siemens Analytical X-Ray Systems, Inc.; Madison,WI 1994.

7. Broach, R. W. CARESS, Argonne National Laboratory, Illinois, 1978.

8. Sheldrick, G. M. SHELXTL Version 6.12, Bruker Analytical X-Ray Systems, Inc.; Madison, WI 2001

9. International Tables for X-Ray Crystallography 1992, Vol. C., Dordrecht: Kluwer Academic Publishers.

10. Flack, H. D. Acta. Cryst., A39, 876-881, 1983.

Definitions:

$\mathrm{wR} 2=\left[\Sigma\left[\mathrm{w}\left(\mathrm{F}_{\mathrm{o}}^{2}-\mathrm{F}_{\mathrm{c}}{ }^{2}\right)^{2}\right] / \Sigma\left[\mathrm{w}\left(\mathrm{F}_{\mathrm{o}}^{2}\right)^{2}\right]\right]^{1 / 2}$

$\mathrm{R} 1=\Sigma|| \mathrm{F}_{\mathrm{o}}|-| \mathrm{F}_{\mathrm{c}}|/ \Sigma| \mathrm{F}_{\mathrm{o}} \mid$

Goof $=\mathrm{S}=\left[\Sigma\left[\mathrm{w}\left(\mathrm{F}_{\mathrm{o}}^{2}-\mathrm{F}_{\mathrm{c}}\right)^{2}\right] /(\mathrm{n}-\mathrm{p})\right]^{1 / 2}$ where $\mathrm{n}$ is the number of reflections and $\mathrm{p}$ is the total

number of parameters refined.

The thermal ellipsoid plot is shown at the $30 \%$ probability level. 


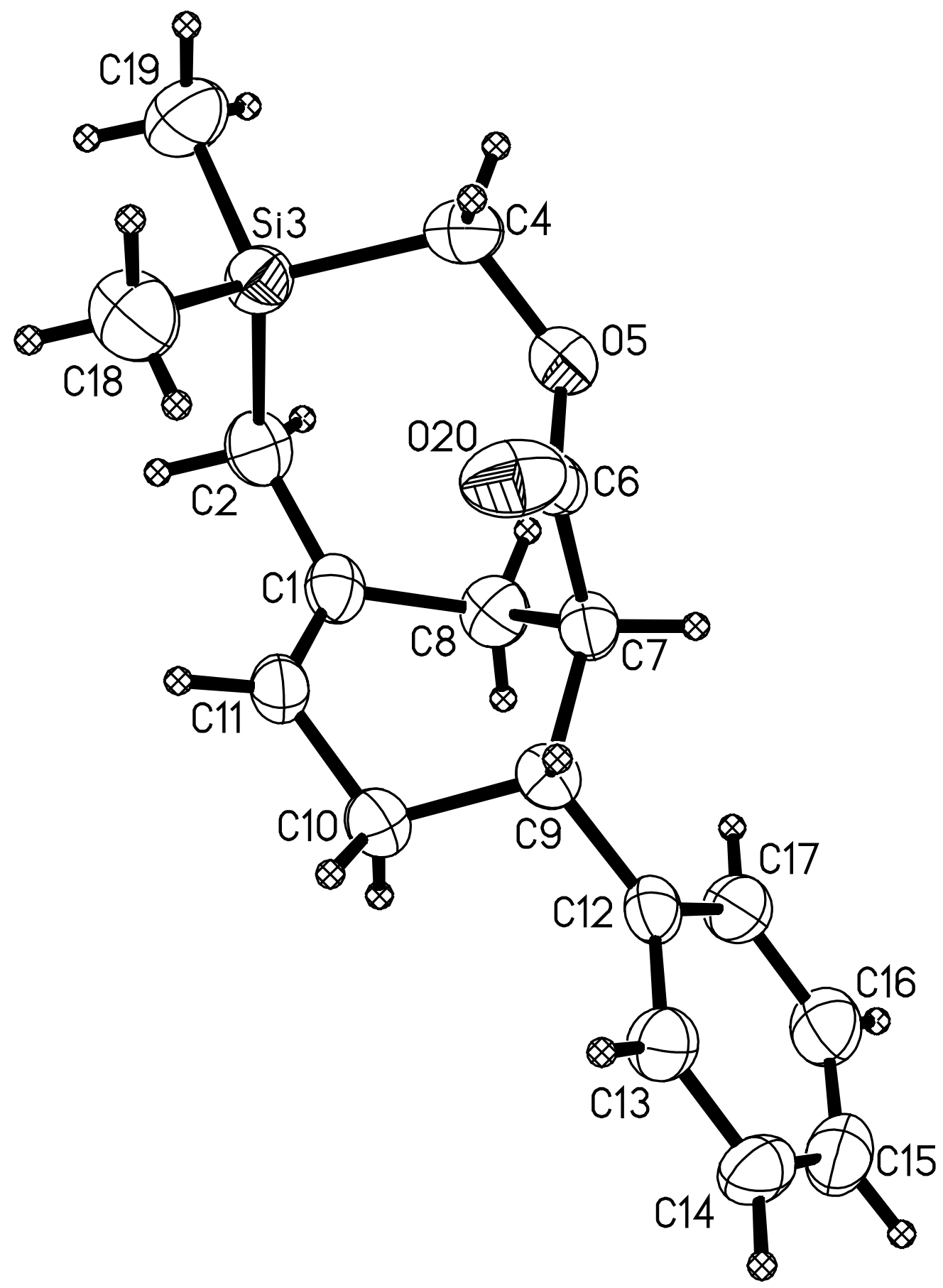




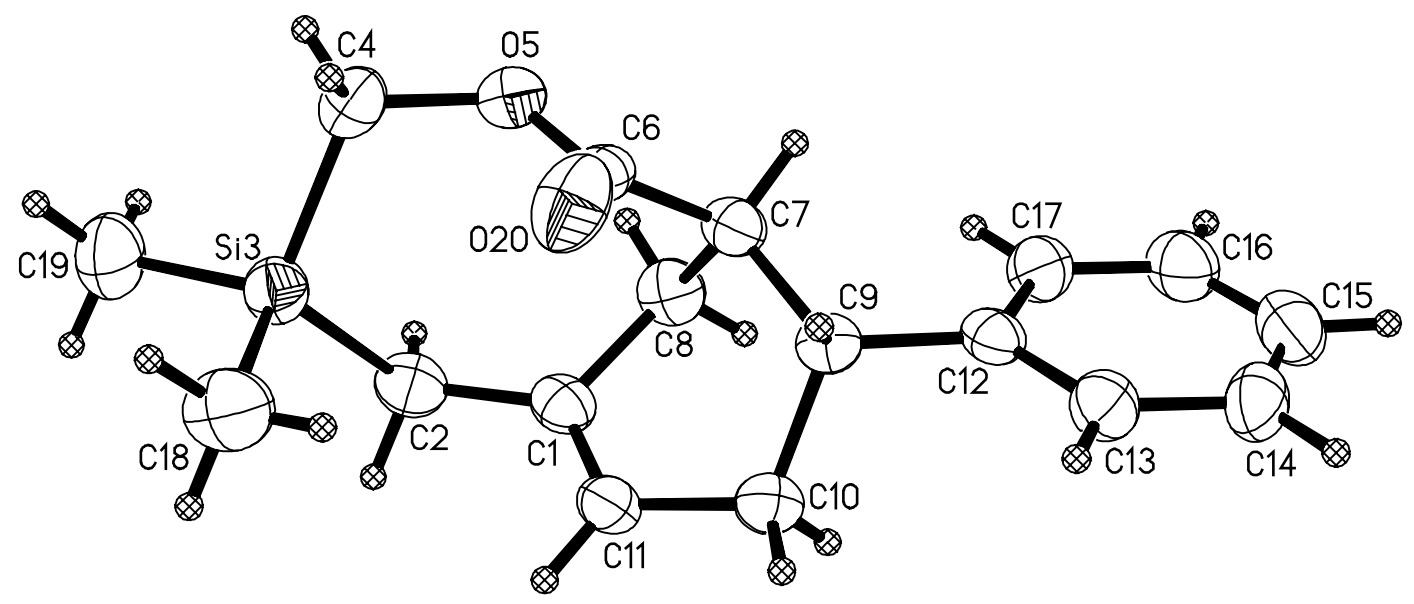

Table 1. Crystal data and structure refinement for $\mathbf{4 f}$.

Identification code

Empirical formula

Formula weight

Temperature

Wavelength

Crystal system

Space group

Unit cell dimensions

Volume

$\mathrm{Z}$

Density (calculated)

Absorption coefficient

$\mathrm{F}(000)$

Crystal color

Crystal size

Theta range for data collection

Index ranges jmw2_05 (John Whitney)

$\mathrm{C}_{17} \mathrm{H}_{22} \mathrm{O}_{2} \mathrm{Si}$

286.44

296(2) K

$0.71073 \AA$

Orthorhombic

Pca2

$\begin{array}{ll}\mathrm{a}=10.0069(13) \AA & \alpha=90^{\circ} . \\ \mathrm{b}=17.429(3) \AA & \beta=90^{\circ} . \\ \mathrm{c}=9.1617(15) \AA & \gamma=90^{\circ} .\end{array}$

1597.9(4) $\AA^{3}$

4

$1.191 \mathrm{Mg} / \mathrm{m}^{3}$

$0.146 \mathrm{~mm}^{-1}$

616

colorless

$0.50 \times 0.50 \times 0.23 \mathrm{~mm}^{3}$

2.34 to $22.50^{\circ}$.

$-1 \leq h \leq 10,-1 \leq k \leq 18,-1 \leq l \leq 9$ 
Reflections collected

Independent reflections

Completeness to theta $=22.50^{\circ}$

Absorption correction

Max. and min. transmission

Refinement method

Data / restraints / parameters

Goodness-of-fit on $\mathrm{F}^{2}$

Final $\mathrm{R}$ indices $[\mathrm{I}>2 \operatorname{sigma}(\mathrm{I})=1101$ data]

$\mathrm{R}$ indices (all data)

Absolute structure parameter

Extinction coefficient

Largest diff. peak and hole
1539

$1272[\mathrm{R}(\mathrm{int})=0.0116]$

$99.4 \%$

None

0.9671 and 0.9305

Full-matrix least-squares on $\mathrm{F}^{2}$

1272 / $1 / 182$

1.074

$\mathrm{R} 1=0.0356, \mathrm{wR} 2=0.0823$

$\mathrm{R} 1=0.0446, \mathrm{wR} 2=0.0873$

$-0.1(2)$

0.0016(8)

0.178 and -0.140 e. $\AA^{-3}$ 
Table 2. Atomic coordinates ( $\mathrm{x} 10^{4}$ ) and equivalent isotropic displacement parameters $\left(\AA^{2} \mathrm{x} 10^{3}\right)$

for $4 \mathbf{f}$. $U(e q)$ is defined as one third of the trace of the orthogonalized $U^{i j}$ tensor.

\begin{tabular}{|c|c|c|c|c|}
\hline & $\mathrm{x}$ & $\mathrm{y}$ & $\mathrm{z}$ & $\mathrm{U}(\mathrm{eq})$ \\
\hline $\mathrm{C}(1)$ & $-1044(4)$ & $6837(2)$ & $1660(5)$ & $58(1)$ \\
\hline$C(2)$ & $-1183(4)$ & $6312(2)$ & $2968(5)$ & $70(1)$ \\
\hline $\operatorname{Si}(3)$ & 199(1) & $6318(1)$ & $4361(2)$ & $65(1)$ \\
\hline$C(4)$ & $521(5)$ & $7336(3)$ & $5006(6)$ & $82(1)$ \\
\hline $\mathrm{O}(5)$ & $-43(3)$ & $7893(2)$ & $4006(3)$ & $79(1)$ \\
\hline$C(6)$ & $563(5)$ & $7966(2)$ & $2717(5)$ & $62(1)$ \\
\hline$C(7)$ & $-434(4)$ & $8194(2)$ & $1558(5)$ & $58(1)$ \\
\hline$C(8)$ & $-1607(4)$ & $7644(2)$ & $1718(6)$ & $67(1)$ \\
\hline $\mathrm{C}(9)$ & $155(4)$ & $8129(2)$ & $22(5)$ & $54(1)$ \\
\hline$C(10)$ & $-59(4)$ & $7307(2)$ & $-624(7)$ & $68(1)$ \\
\hline $\mathrm{C}(11)$ & $-281(4)$ & $6696(2)$ & $531(5)$ & $65(1)$ \\
\hline$C(12)$ & $-340(4)$ & $8720(2)$ & $-1056(4)$ & $54(1)$ \\
\hline$C(13)$ & $390(4)$ & $8877(2)$ & $-2301(6)$ & $67(1)$ \\
\hline $\mathrm{C}(14)$ & $-30(5)$ & $9409(3)$ & $-3319(6)$ & $80(1)$ \\
\hline$C(15)$ & $-1199(6)$ & $9803(2)$ & $-3088(7)$ & $84(2)$ \\
\hline$C(16)$ & $-1933(5)$ & $9652(2)$ & $-1883(7)$ & $82(1)$ \\
\hline$C(17)$ & $-1522(4)$ & $9119(2)$ & $-873(6)$ & $70(1)$ \\
\hline$C(18)$ & $1743(4)$ & $5900(3)$ & $3556(7)$ & $98(2)$ \\
\hline$C(19)$ & $-335(6)$ & $5755(3)$ & $5992(7)$ & $102(2)$ \\
\hline $\mathrm{O}(20)$ & $1718(3)$ & $7829(2)$ & $2524(4)$ & $91(1)$ \\
\hline
\end{tabular}


Table 3. Bond lengths $[\AA]$ and angles $\left[^{\circ}\right]$ for $\mathbf{4 f}$.

\begin{tabular}{ll}
\hline $\mathrm{C}(1)-\mathrm{C}(11)$ & $1.309(6)$ \\
$\mathrm{C}(1)-\mathrm{C}(2)$ & $1.514(6)$ \\
$\mathrm{C}(1)-\mathrm{C}(8)$ & $1.516(5)$ \\
$\mathrm{C}(2)-\mathrm{Si}(3)$ & $1.882(5)$ \\
$\mathrm{Si}(3)-\mathrm{C}(18)$ & $1.861(5)$ \\
$\mathrm{Si}(3)-\mathrm{C}(19)$ & $1.866(6)$ \\
$\mathrm{Si}(3)-\mathrm{C}(4)$ & $1.897(5)$ \\
$\mathrm{C}(4)-\mathrm{O}(5)$ & $1.449(5)$ \\
$\mathrm{O}(5)-\mathrm{C}(6)$ & $1.334(5)$ \\
$\mathrm{C}(6)-\mathrm{O}(20)$ & $1.193(5)$ \\
$\mathrm{C}(6)-\mathrm{C}(7)$ & $1.510(6)$ \\
$\mathrm{C}(7)-\mathrm{C}(8)$ & $1.523(5)$ \\
$\mathrm{C}(7)-\mathrm{C}(9)$ & $1.531(6)$ \\
$\mathrm{C}(9)-\mathrm{C}(12)$ & $1.511(6)$ \\
$\mathrm{C}(9)-\mathrm{C}(10)$ & $1.564(5)$ \\
$\mathrm{C}(10)-\mathrm{C}(11)$ & $1.518(6)$ \\
$\mathrm{C}(12)-\mathrm{C}(13)$ & $1.382(6)$ \\
$\mathrm{C}(12)-\mathrm{C}(17)$ & $1.382(5)$ \\
$\mathrm{C}(13)-\mathrm{C}(14)$ & $1.381(7)$ \\
$\mathrm{C}(14)-\mathrm{C}(15)$ & $1.374(6)$ \\
$\mathrm{C}(15)-\mathrm{C}(16)$ & $1.352(7)$ \\
$\mathrm{C}(16)-\mathrm{C}(17)$ & $1.374(6)$ \\
$\mathrm{C}(11)-\mathrm{C}(1)-\mathrm{C}(2)$ & $124.5(4)$ \\
$\mathrm{C}(11)-\mathrm{C}(1)-\mathrm{C}(8)$ & $114.7(4)$ \\
$\mathrm{C}(2)-\mathrm{C}(1)-\mathrm{C}(8)$ & $119.9(4)$ \\
$\mathrm{C}(1)-\mathrm{C}(2)-\mathrm{Si}(3)$ & $117.8(3)$ \\
$\mathrm{C}(18)-\mathrm{Si}(3)-\mathrm{C}(19)$ & $110.4(3)$ \\
$\mathrm{C}(18)-\mathrm{Si}(3)-\mathrm{C}(2)$ & $109.8(2)$ \\
$\mathrm{C}(19)-\mathrm{Si}(3)-\mathrm{C}(2)$ & $109.2(2)$ \\
$\mathrm{C}(18)-\mathrm{Si}(3)-\mathrm{C}(4)$ & $110.4(2)$ \\
$\mathrm{C}(19)-\mathrm{Si}(3)-\mathrm{C}(4)$ & $106.9(2)$ \\
$\mathrm{C}(2)-\mathrm{Si}(3)-\mathrm{C}(4)$ & $110.0(2)$ \\
$\mathrm{O}(5)-\mathrm{C}(4)-\mathrm{Si}(3)$ & $111.3(3)$ \\
& \\
& \\
&
\end{tabular}




$\begin{array}{ll}\mathrm{C}(6)-\mathrm{O}(5)-\mathrm{C}(4) & 116.5(4) \\ \mathrm{O}(20)-\mathrm{C}(6)-\mathrm{O}(5) & 123.5(5) \\ \mathrm{O}(20)-\mathrm{C}(6)-\mathrm{C}(7) & 126.0(5) \\ \mathrm{O}(5)-\mathrm{C}(6)-\mathrm{C}(7) & 110.3(4) \\ \mathrm{C}(6)-\mathrm{C}(7)-\mathrm{C}(8) & 106.0(4) \\ \mathrm{C}(6)-\mathrm{C}(7)-\mathrm{C}(9) & 111.8(3) \\ \mathrm{C}(8)-\mathrm{C}(7)-\mathrm{C}(9) & 109.8(4) \\ \mathrm{C}(1)-\mathrm{C}(8)-\mathrm{C}(7) & 107.2(3) \\ \mathrm{C}(12)-\mathrm{C}(9)-\mathrm{C}(7) & 115.1(3) \\ \mathrm{C}(12)-\mathrm{C}(9)-\mathrm{C}(10) & 109.4(4) \\ \mathrm{C}(7)-\mathrm{C}(9)-\mathrm{C}(10) & 111.3(4) \\ \mathrm{C}(11)-\mathrm{C}(10)-\mathrm{C}(9) & 113.5(4) \\ \mathrm{C}(1)-\mathrm{C}(11)-\mathrm{C}(10) & 120.3(4) \\ \mathrm{C}(13)-\mathrm{C}(12)-\mathrm{C}(17) & 117.0(4) \\ \mathrm{C}(13)-\mathrm{C}(12)-\mathrm{C}(9) & 120.1(4) \\ \mathrm{C}(17)-\mathrm{C}(12)-\mathrm{C}(9) & 123.0(4) \\ \mathrm{C}(14)-\mathrm{C}(13)-\mathrm{C}(12) & 122.0(4) \\ \mathrm{C}(15)-\mathrm{C}(14)-\mathrm{C}(13) & 119.4(5) \\ \mathrm{C}(16)-\mathrm{C}(15)-\mathrm{C}(14) & 119.4(5) \\ \mathrm{C}(15)-\mathrm{C}(16)-\mathrm{C}(17) & 121.3(5) \\ \mathrm{C}(16)-\mathrm{C}(17)-\mathrm{C}(12) & 121.0(5)\end{array}$


Table 4. Anisotropic displacement parameters $\left(\AA^{2} \times 10^{3}\right)$ for $\mathbf{4 f}$. The anisotropic displacement factor exponent takes the form: $-2 \pi^{2}\left[h^{2} a^{* 2} U^{11}+\ldots+2 h k a^{*} b^{*} U^{12}\right]$

\begin{tabular}{|c|c|c|c|c|c|c|}
\hline & $\mathrm{U}^{11}$ & $\mathrm{U}^{22}$ & $U^{33}$ & $\mathrm{U}^{23}$ & $\mathrm{U}^{13}$ & $\mathrm{U}^{12}$ \\
\hline $\mathrm{C}(1)$ & $53(2)$ & $51(2)$ & $70(3)$ & $-6(2)$ & $-9(3)$ & $-6(2)$ \\
\hline $\mathrm{C}(2)$ & $62(2)$ & $66(2)$ & $81(4)$ & $-7(3)$ & $2(3)$ & $-8(2)$ \\
\hline $\operatorname{Si}(3)$ & $67(1)$ & $62(1)$ & $65(1)$ & $3(1)$ & $-1(1)$ & $0(1)$ \\
\hline $\mathrm{C}(4)$ & $107(4)$ & $81(3)$ & $56(3)$ & $5(3)$ & $-9(3)$ & $-6(3)$ \\
\hline $\mathrm{O}(5)$ & $114(2)$ & $65(2)$ & $58(3)$ & $-8(2)$ & $-2(2)$ & $0(2)$ \\
\hline $\mathrm{C}(6)$ & $78(3)$ & $57(2)$ & $51(3)$ & $-6(2)$ & $-2(3)$ & $-18(2)$ \\
\hline$C(7)$ & $60(2)$ & $49(2)$ & $64(3)$ & $-5(2)$ & $-3(3)$ & $1(2)$ \\
\hline $\mathrm{C}(8)$ & $53(2)$ & $73(3)$ & $75(3)$ & $-3(3)$ & $1(2)$ & $10(2)$ \\
\hline $\mathrm{C}(9)$ & $51(2)$ & $56(2)$ & $54(2)$ & $-5(2)$ & $0(2)$ & $0(2)$ \\
\hline $\mathrm{C}(10)$ & $80(3)$ & $62(2)$ & $61(3)$ & $-8(3)$ & $1(3)$ & $12(2)$ \\
\hline $\mathrm{C}(11)$ & $79(3)$ & $50(2)$ & $66(3)$ & $-8(2)$ & $-14(3)$ & $11(2)$ \\
\hline$C(12)$ & $57(2)$ & $45(2)$ & $61(4)$ & $-8(2)$ & $-8(2)$ & $-3(2)$ \\
\hline$C(13)$ & $69(3)$ & $63(3)$ & $69(3)$ & $2(3)$ & $0(3)$ & $-9(2)$ \\
\hline$C(14)$ & $99(4)$ & $74(3)$ & $65(3)$ & $14(3)$ & $-12(3)$ & $-30(3)$ \\
\hline$C(15)$ & $100(4)$ & $60(3)$ & $93(4)$ & $7(3)$ & $-36(4)$ & $-7(3)$ \\
\hline$C(16)$ & $85(3)$ & $72(3)$ & $89(4)$ & $-2(3)$ & $-18(4)$ & $16(3)$ \\
\hline $\mathrm{C}(17)$ & $74(3)$ & $69(2)$ & $67(3)$ & $-1(3)$ & $-7(3)$ & $15(2)$ \\
\hline $\mathrm{C}(18)$ & $77(3)$ & 113(4) & 104(4) & $-18(3)$ & $-8(3)$ & $17(3)$ \\
\hline$C(19)$ & $124(4)$ & $92(3)$ & $91(4)$ & $24(3)$ & $-2(4)$ & $-5(3)$ \\
\hline $\mathrm{O}(20)$ & $66(2)$ & $128(3)$ & $80(2)$ & $20(2)$ & $-14(2)$ & $-20(2)$ \\
\hline
\end{tabular}


Table 5. Hydrogen coordinates $\left(\times 10^{4}\right)$ and isotropic displacement parameters $\left(\AA^{2} \times 10\right.$ 3) for $4 \mathbf{f}$.

\begin{tabular}{|c|c|c|c|c|}
\hline & $\mathrm{x}$ & $\mathrm{y}$ & $\mathrm{z}$ & $\mathrm{U}(\mathrm{eq})$ \\
\hline $\mathrm{H}(2 \mathrm{~A})$ & -1278 & 5791 & 2610 & 84 \\
\hline $\mathrm{H}(2 \mathrm{~B})$ & -2009 & 6443 & 3463 & 84 \\
\hline $\mathrm{H}(4 \mathrm{~A})$ & 131 & 7406 & 5966 & 98 \\
\hline $\mathrm{H}(4 \mathrm{~B})$ & 1477 & 7419 & 5086 & 98 \\
\hline $\mathrm{H}(7 \mathrm{~A})$ & -737 & 8722 & 1731 & 69 \\
\hline $\mathrm{H}(8 \mathrm{~A})$ & -2060 & 7729 & 2639 & 80 \\
\hline $\mathrm{H}(8 \mathrm{~B})$ & -2242 & 7721 & 932 & 80 \\
\hline $\mathrm{H}(9 \mathrm{~A})$ & 1122 & 8204 & 115 & 65 \\
\hline $\mathrm{H}(10 \mathrm{~A})$ & -826 & 7317 & -1272 & 82 \\
\hline $\mathrm{H}(10 \mathrm{~B})$ & 717 & 7169 & -1202 & 82 \\
\hline $\mathrm{H}(11 \mathrm{~A})$ & 128 & 6220 & 436 & 78 \\
\hline $\mathrm{H}(13 \mathrm{~A})$ & 1188 & 8616 & -2458 & 80 \\
\hline $\mathrm{H}(14 \mathrm{~A})$ & 475 & 9499 & -4154 & 95 \\
\hline $\mathrm{H}(15 \mathrm{~A})$ & -1484 & 10171 & -3755 & 101 \\
\hline $\mathrm{H}(16 \mathrm{~A})$ & -2732 & 9913 & -1735 & 99 \\
\hline $\mathrm{H}(17 \mathrm{~A})$ & -2046 & 9026 & -54 & 84 \\
\hline $\mathrm{H}(18 \mathrm{~A})$ & 1566 & 5385 & 3237 & 147 \\
\hline $\mathrm{H}(18 \mathrm{C})$ & 2439 & 5895 & 4277 & 147 \\
\hline $\mathrm{H}(18 \mathrm{D})$ & 2020 & 6205 & 2737 & 147 \\
\hline $\mathrm{H}(19 \mathrm{C})$ & -509 & 5234 & 5709 & 153 \\
\hline H(19D) & -1133 & 5976 & 6393 & 153 \\
\hline $\mathrm{H}(19 \mathrm{~A})$ & 361 & 5765 & 6712 & 153 \\
\hline
\end{tabular}


Table 6. Torsion angles $\left[^{\circ}\right]$ for $\mathbf{4 f}$.

\begin{tabular}{lc}
\hline $\mathrm{C}(11)-\mathrm{C}(1)-\mathrm{C}(2)-\mathrm{Si}(3)$ & $77.7(5)$ \\
$\mathrm{C}(8)-\mathrm{C}(1)-\mathrm{C}(2)-\mathrm{Si}(3)$ & $-90.8(4)$ \\
$\mathrm{C}(1)-\mathrm{C}(2)-\mathrm{Si}(3)-\mathrm{C}(18)$ & $-68.0(4)$ \\
$\mathrm{C}(1)-\mathrm{C}(2)-\mathrm{Si}(3)-\mathrm{C}(19)$ & $170.7(3)$ \\
$\mathrm{C}(1)-\mathrm{C}(2)-\mathrm{Si}(3)-\mathrm{C}(4)$ & $53.6(4)$ \\
$\mathrm{C}(18)-\mathrm{Si}(3)-\mathrm{C}(4)-\mathrm{O}(5)$ & $103.8(4)$ \\
$\mathrm{C}(19)-\mathrm{Si}(3)-\mathrm{C}(4)-\mathrm{O}(5)$ & $-136.0(4)$ \\
$\mathrm{C}(2)-\mathrm{Si}(3)-\mathrm{C}(4)-\mathrm{O}(5)$ & $-17.5(4)$ \\
$\mathrm{Si}(3)-\mathrm{C}(4)-\mathrm{O}(5)-\mathrm{C}(6)$ & $-71.0(5)$ \\
$\mathrm{C}(4)-\mathrm{O}(5)-\mathrm{C}(6)-\mathrm{O}(20)$ & $-27.0(6)$ \\
$\mathrm{C}(4)-\mathrm{O}(5)-\mathrm{C}(6)-\mathrm{C}(7)$ & $149.5(4)$ \\
$\mathrm{O}(20)-\mathrm{C}(6)-\mathrm{C}(7)-\mathrm{C}(8)$ & $127.4(5)$ \\
$\mathrm{O}(5)-\mathrm{C}(6)-\mathrm{C}(7)-\mathrm{C}(8)$ & $-49.0(5)$ \\
$\mathrm{O}(20)-\mathrm{C}(6)-\mathrm{C}(7)-\mathrm{C}(9)$ & $7.8(6)$ \\
$\mathrm{O}(5)-\mathrm{C}(6)-\mathrm{C}(7)-\mathrm{C}(9)$ & $-168.6(4)$ \\
$\mathrm{C}(11)-\mathrm{C}(1)-\mathrm{C}(8)-\mathrm{C}(7)$ & $-52.3(5)$ \\
$\mathrm{C}(2)-\mathrm{C}(1)-\mathrm{C}(8)-\mathrm{C}(7)$ & $117.3(4)$ \\
$\mathrm{C}(6)-\mathrm{C}(7)-\mathrm{C}(8)-\mathrm{C}(1)$ & $-53.5(5)$ \\
$\mathrm{C}(9)-\mathrm{C}(7)-\mathrm{C}(8)-\mathrm{C}(1)$ & $67.5(5)$ \\
$\mathrm{C}(6)-\mathrm{C}(7)-\mathrm{C}(9)-\mathrm{C}(12)$ & $-146.1(3)$ \\
$\mathrm{C}(8)-\mathrm{C}(7)-\mathrm{C}(9)-\mathrm{C}(12)$ & $96.5(4)$ \\
$\mathrm{C}(6)-\mathrm{C}(7)-\mathrm{C}(9)-\mathrm{C}(10)$ & $88.7(4)$ \\
$\mathrm{C}(8)-\mathrm{C}(7)-\mathrm{C}(9)-\mathrm{C}(10)$ & $-28.7(5)$ \\
$\mathrm{C}(12)-\mathrm{C}(9)-\mathrm{C}(10)-\mathrm{C}(11)$ & $-150.7(4)$ \\
$\mathrm{C}(7)-\mathrm{C}(9)-\mathrm{C}(10)-\mathrm{C}(11)$ & $-22.4(5)$ \\
$\mathrm{C}(2)-\mathrm{C}(1)-\mathrm{C}(11)-\mathrm{C}(10)$ & $-171.4(4)$ \\
$\mathrm{C}(8)-\mathrm{C}(1)-\mathrm{C}(11)-\mathrm{C}(10)$ & $-2.3(6)$ \\
$\mathrm{C}(9)-\mathrm{C}(10)-\mathrm{C}(11)-\mathrm{C}(1)$ & $41.6(5)$ \\
$\mathrm{C}(7)-\mathrm{C}(9)-\mathrm{C}(12)-\mathrm{C}(13)$ & $159.9(3)$ \\
$\mathrm{C}(10)-\mathrm{C}(9)-\mathrm{C}(12)-\mathrm{C}(13)$ & $-74.0(4)$ \\
$\mathrm{C}(7)-\mathrm{C}(9)-\mathrm{C}(12)-\mathrm{C}(17)$ & $-20.9(5)$ \\
$\mathrm{C}(10)-\mathrm{C}(9)-\mathrm{C}(12)-\mathrm{C}(17)$ & $105.3(4)$ \\
$\mathrm{C}(17)-\mathrm{C}(12)-\mathrm{C}(13)-\mathrm{C}(14)$ & $0.3(6)$ \\
$\mathrm{C}(9)-\mathrm{C}(12)-\mathrm{C}(13)-\mathrm{C}(14)$ & \\
& \\
&
\end{tabular}




$\begin{array}{lc}\mathrm{C}(12)-\mathrm{C}(13)-\mathrm{C}(14)-\mathrm{C}(15) & 0.8(7) \\ \mathrm{C}(13)-\mathrm{C}(14)-\mathrm{C}(15)-\mathrm{C}(16) & -1.4(7) \\ \mathrm{C}(14)-\mathrm{C}(15)-\mathrm{C}(16)-\mathrm{C}(17) & 1.0(7) \\ \mathrm{C}(15)-\mathrm{C}(16)-\mathrm{C}(17)-\mathrm{C}(12) & 0.1(7) \\ \mathrm{C}(13)-\mathrm{C}(12)-\mathrm{C}(17)-\mathrm{C}(16) & -0.7(6) \\ \mathrm{C}(9)-\mathrm{C}(12)-\mathrm{C}(17)-\mathrm{C}(16) & -180.0(4)\end{array}$

